Max-Planck-Institut für demografische Forschung

Max Planck Institute for Demographic Research

Konrad-Zuse-Strasse 1 - D-18057 Rostock = Germany = Tel +49 (0) 3812081 - 0 - Fax +49 (0) 3812081 - 202 - www.demogr.mpg.de

MPIDR Working Paper WP 2020-008 I February 2020

https://doi.org/10.4054/MPIDR-WP-2020-008

Family formation trajectories and migration status in the United States, 1970-2010

Andres Castro I castro@demogr.mpg.de

This working paper has been approved for release by: Mathias Lerch (lerch@demogr.mpg.de),

Deputy Head of the Laboratory of Fertility and Well-Being.

(ㄷ) Copyright is held by the authors.

Working papers of the Max Planck Institute for Demographic Research receive only limited review. Views or opinions expressed in working papers are attributable to the authors and do not necessarily reflect those of the Institute. 


\title{
Family formation trajectories and migration status in the United States, 1970-2010
}

\begin{abstract}
Studies often explain differences in family outcomes by migration status by referring to four hypotheses: socialization, selection, disruption, and assimilation/adaptation. These hypotheses were initially formulated as competing explanations, but some scholars have argued that they are complementary. Currently, however, this complementary relationship is not well understood. In this paper, I draw on these hypotheses jointly to examine family formation and dissolution trajectories in the US by migration status based on quantitative, nationally representative evidence. For the analysis, I use retrospective information on marriages, unions, and births to men and women from five waves of the National Survey of Family Growth (19952015) to construct a six-category typology of family trajectories. This typology divides men and women into groups with similar family formation and dissolution trajectories. I correlate this typology with information on each respondent's race/ethnicity, educational attainment, place of birth, and age at migration. The patterns of these correlations demonstrate that gender and class explain differences in family trajectories to a greater extent than migration status. The relationship between family paths and migration depends on the migrants' sex, age at migration, and socioeconomic background. These multiple dependencies underline the need for complementary rather than competing explanations. In addition, I examine differences in the prevalence of racially exogamous and endogamous marriages/unions in order to explore the possibility that other social mechanisms are driving these sex- and class-specific relationships.
\end{abstract}




\section{Introduction}

Although migration, fertility, and partnership formation are intertwined, quantitative studies have rarely examined these events jointly. Instead, the relationship between migration and family formation is usually studied in one direction or the other. International migration and family formation events are seldom seen as being part of a larger process, and the importance of migrants' age at migration and social class is sometimes underestimated (Lindstrom and Giorguli Saucedo 2002; Raley, Durden, and Wildsmith 2004).

Moreover, these studies tend to concentrate on comparing mean levels of fertility and the timing of family formation events by migration status and migrant generation (Kulu and GonzálezFerrer 2014; Parrado and Morgan 2008). These comparisons typically test the competing relevance of socialization, selection, disruption, and assimilation as factors in explanations of the differences in the family outcomes and family trajectories of migrants and non-migrants (Kulu 2005). While overview studies have concluded that competing hypotheses are indeed complementary, why this is the case is still poorly understood (Kulu and Hannemann 2016). In this work, I explore how the family trajectories of migrants differ according to sex, socioeconomic status, and age at migration. My description of the heterogeneity in family trajectories across these three dimensions helps shed light on why previously proposed explanations are complementary. The evidence presented here suggests that the differences in the family trajectories among migrants, and between migrants and the native-born population, are mainly attributable to class and gender relations. The intersection of these two concepts explains why, for example, the assimilation hypothesis appears to be valid among high-class women, whereas the socialization hypothesis seems to better account for the experiences of low-class men. 
More specifically, by examining the heterogeneity in family formation and dissolution trajectories among men and women in the United States (US) from 1970 to 2010, this paper contributes to our understanding of how previously proposed explanations for these patterns are complementary. The analysis focuses on the propensity of individuals to follow certain family paths based on their sex, race/ethnicity, educational attainment, and age at migration. This approach allows me to capture gender and class differences in the family formation trajectories of both migrants and native-born individuals. I argue that a gender- and class-based interpretation of these patterns brings together insights from previous research, and provides a theoretical framework for understanding the multiplicity of ways in which migration and family are related.

This is an important contribution given the increasing significance of migration in contemporary societies. The demand for research on these issues is strong, not just in the US, but in other developed nations as well, such as Canada, Germany, Sweden, Spain, and France (Edmonston 2006; Foner and Dreby 2011; Kulu and González-Ferrer 2014). As the national origins and the migrant generations of the populations of these societies are becoming increasingly mixed, there is a pressing need in these countries to understand how partnership formation, fertility, and migration are related. Describing the heterogeneity of the family paths of migrants, and how the trajectories of migrants compare with those of the native-born population, represents a first step toward understanding migration, fertility, and partnership formation (dissolution) as outcomes embedded in gender and class relations; and is the main objective of this paper.

The last four decades of the $20^{\text {th }}$ century in the US offer a relevant context for this research. During this period, the socioeconomic and demographic composition of migrants to the US diversified (Donato et al. 2010; Kandel and Massey 2002; Rendall and Parker 2014), and trends 
in the transition to childbearing and family formation in the US also changed substantially (Bianchi 2011; Furstenberg 2014). The increasing heterogeneity in both migration flows and family formation dynamics in the US offers us a unique opportunity to study how family formation occurs among migrants, and how these patterns compare to those of the native-born. Describing this heterogeneity should shed light on the complementary nature of previously proposed explanations (which are often mistakenly seen as competing).

Using retrospective information of five waves of the National Survey of Family Growth (NSFG), I reconstruct the fertility and partnership trajectories (hereafter, family trajectories) of individuals born between 1950 and 1976. Family trajectories start at age 15, when most people are single and childless, and finish at age 39 (see the justification for using this cut-off point below). Using sequence analysis and clustering techniques, I assign these individual family formation trajectories to a six-category typology based on their overall similarities; i.e., based on the occurrence, timing, and duration of births (parities), unions, and marriages.

Furthermore, I use multinomial logistic models to estimate conditional distributions of this typology by race/ethnicity, age at migration (using US-born individuals as the reference category), and educational attainment. I call these conditional distributions family profiles. Although I include control variables such as birth cohort and religious affiliation in estimating these conditional distributions, family profiles are above all descriptive tools; i.e., distributions that reflect the propensity of individuals to experience a typical family path. This notion of typicall family path, echoes the Garip's notion of typical migration path (Garip 2012).

In the final section, I use Linear Probability Models (LPM) to compare the propensities of individuals to have a partner who is part of the population majority (Non-Hispanic white) and a 
partner who belongs to the same racial/ethnic group (endogamy), controlling by birth cohort, religious affiliation, and educational attainment. I use these results to speculate on the mechanisms that underlie the association between migration and family profiles.

This study is the first to examine heterogeneity in family trajectories among native-born and migrant groups in the US along several dimensions: sex, race/ethnicity, age at migration, and educational attainment using nationally representative quantitative information. The patterned differences found across family profiles along these dimensions demonstrate the gendered and socially stratified nature of family formation dynamics, and the various ways in which migration relates to individual family formation paths.

Although migration is a disruptive event for family formation trajectories, gender and social class differences are the main differentiation axes for family formation in the US for both migrants and US-born men and women. By highlighting that gender and class structure influence family formation dynamics more than migration status, the findings of this paper help to reconcile the apparently contradictory (competing) nature of previously proposed explanations for the relationship between migration and family formation. The evidence presented here supports the findings of an extensive body of qualitative literature (Bledsoe 2004; K. Donato 2010; Herrera 2013; Hondagneu-Sotelo 1994), and should encourage migration scholars to examine the heterogeneity of family formation processes as a means of capturing class and gender relations.

\section{Migration and family dynamics at origin and at destination}

The national origins of migrants to the US in the second half of the $20^{\text {th }}$ century differed significantly from those of their counterparts in the first half of that century. The numbers of 
migrants from European countries declined, while the numbers of migrants from Asian, Latin American, and Caribbean countries increased substantially (Castles, De Haas, and Miller 2014:6). In 1930, $83 \%$ of migrants living in the US were of European origin, while $1.9 \%$ were of Asian origin, and 5.6\% were of Latin American and Caribbean (LAC) origin. By 1990, these shares had changed to $23 \%, 26 \%$, and $44 \%$, respectively; and by 2000 , migrants from LAC countries had become the majority, representing 52\% of the foreign-born population (Gibson and Jung 2006). The largest share of this migrant population came from Mexico (Garip 2012, 2017).

The factors that triggered migration from LAC to the US during this period were predominantly economic (Clark, Hatton, and Williamson 2003; Donato et al. 2010). Most of these migrants moved to the US in search of better economic opportunities (Massey, Durand, and Pren 2014; Piore 1979). These moves often occurred in response to targeted labor recruitment efforts, such as state-directed policies aimed at hiring male workers. The most salient example of these policies is the Bracero program, which brought approximately 4.6 million Mexican men to work in the US between 1942 and 1964 (Garip 2012). In addition to this large wave of labor migrants, smaller numbers of migrants from LAC were moving to the US to improve their professional skills through participation in specialized training and higher education (Rendall and Parker 2014). The women who migrated did so mainly for family reunification reasons, as the labor recruitment policies did not target female workers. Because of this sharp gender divide in the targeting of migration policies, the migration trajectories of women were much more attached to their family paths than those of men (Curran and Rivero-Fuentes 2003; K. M. Donato 2010; Kanaiaupuni 2000).

After arriving in the US, these migrants typically found that they had economic and financial opportunities that differed from those in their country of origin, but also that they faced 
normative expectations regarding family formation that diverged from those in their home country (Kulu and Hannemann 2016; Stephen and Bean 1992). The significance of this confluence of opportunities and expectations depended on how different (or similar) the family practices (typical ages at union/marriage, marital stability, degree of ethnic endogamy, etc.) were at origin and at destination, and at what ages the migrants moved.

There are important differences between the US and LAC in terms of normative family practices. Some of these differences are to be expected, given the differential levels of economic development and religious affiliation traditions in the US and LAC (Furstenberg 2013); while others are more idiosyncratic, and deserve some attention given their potential implications for the family trajectories of migrants (Adserà and Ferrer 2015).

Family formation dynamics in the US differ from those in other high-income nations in three main ways. First, although the transitions to first birth and first marriage are substantially delayed in the US, fertility in the US has not reached the lowest-low or low levels that have been observed in some European nations (Bianchi and Casper 2000). During the second half of the $20^{\text {th }}$ century, both period and cohort fertility remained stable in the US, hovering at levels of around two children per woman (Monte and Ellis 2014). Second, also during this period, increasing levels of marital instability and single motherhood among low socioeconomic status groups coexisted with positive views of the importance of marriage for individual fulfillment and societal well-being (Coontz 2014; Hayford, Guzzo, and Smock 2014; Thornton and YoungDeMarco 2001). Third, there are substantial differences in the timing of fertility across socioeconomic groups in the US that have produced bimodal distributions in the ages at first birth (Sullivan 2005). Overall, family dynamics in the US are both stratified and changing. These 
two characteristics suggest that the assimilation of migrants in the US could take different forms depending on their socioeconomic background, as well as on the behavior of the majority.

In LAC, the configuration of changes in family practices has been rather different. In the 1950s, fertility was high in the region (six children per women), except among countries of the Southern Cone, including Argentina and Uruguay. Over the following two decades, fertility levels in LAC declined rapidly in response to urbanization, increasing educational attainment, and increasing use of effective birth control (Guzmán et al. 2006). Since that time, the mean age at first birth has remained stable in many LAC countries, albeit with significant differences by socioeconomic status (Esteve and Florez-Paredes 2018). The mean age at first birth has declined most sharply among low-SES women, whereas the postponement of childbearing has been a long-standing practice among high-SES women. Marital instability has increased in a context in which informal unions and formal marriages have endured as socially equivalent alternatives for organizing family life (Castro-Martín 2002). These changes in family formation patterns have occurred alongside moderate levels of socioeconomic development and high levels of inequality (Torche 2014).

Two similarities between the family formation dynamics in the US and LAC countries are worth noting. First, educational attainment has played an increasing role in determining family outcomes; i.e. the timing and stability of unions, and the timing and quantity of children (Castro Martin and Juarez 1995; Furstenberg 2014). Second, the family formation trajectories that distinguish the life courses of low-SES and high-SES individuals have become increasingly polarized (García and de Oliveira 2011; Landale and Oropesa 2007). In short, in both the US and LAC countries, family formation trajectories are becoming increasingly differentiated by socioeconomic status. 
Changes in the family formation patterns in LAC imply that the motivations and the means to migrate may differ according to migrants' socioeconomic backgrounds, as qualitative research on family dynamics among migrants has suggested (Hondagneu-Sotelo 1994). High-SES individuals tend to have the material means for relatively constraint-free migration due to their delayed transitions to childbearing and marriage, greater financial resources, and smaller families. By postponing childbearing, individual migrants, and women in particular, have more time to gather information and set goals associated with international moves. Individual migrants with no children may plan to enroll in higher education or specialized training at the destination country. Information about how to achieve these goals is often transmitted through institutions of formal education, which high-SES individuals have privileged access to in their countries of origin (Torche 2014). Hence, the family trajectories of high-SES migrants are expected to be at the front line of family change in their countries of origin. Moreover, among high-SES individuals, migration is likely to further advance family change in the direction of later transitions to union formation, marriage, and childbearing; and, in turn, of lower fertility.

Among low-SES migrants, family formation tends to occur before migration, and the motivations and means to migrate differ from those of their high-SES counterparts. Low-SES migrants typically pursue a household strategy, in which one family member - often the household head or the oldest son - migrates as a targeted earner (Hondagneu-Sotelo 1994; Landale and Oropesa 2007). Depending on the socioeconomic conditions achieved by the first migrant, the other family members may or may not follow (Garip 2012; Lindstrom and GiorguliSaucedo 2007; Massey et al. 2014). Hence, for low-SES individuals, emigration is not likely to imply substantial delays in family formation. On the contrary, to the extent that family support is a precondition for the targeted earner to migrate, migration may be associated with the early 
development of strong family ties. Moreover, in the context of family reunification, a formal marriage may be necessary to secure the right of a partner to migrate.

The theories that have been applied in examining these issues have not paid enough attention to the heterogeneity of these patterns. Instead, they have tended to focus on differences in the mean levels of fertility and the timing of family formation. In the next section, I discuss the main insights of these theories, along with a new gender- and class-based framework that could bring these insights together.

\section{Theoretical background}

Studies looking at how fertility and partnership schedules differ between migrants and nonmigrants have been conducted for almost all high-income countries that have been primary destinations of international migrants since 1950 (Adserà and Ferrer 2015; Kulu and GonzálezFerrer 2014). These studies have generally relied on four key hypotheses to explain the differences in the fertility and marriage/union formation outcomes of migrants and non-migrants: selection, socialization, disruption, and adaptation/assimilation. Because these hypotheses have tended to focus on single events, they have mainly been concerned with intensity (e.g., total fertility, first or second births) and timing (e.g., age at first birth).

The first two hypotheses focus on conditions before migration, such as the family norms and values migrants learned during childhood (socialization), or whether migrants have less familyoriented attitudes (selection). For example, scholars have attributed the higher fertility observed among African migrants in Spain (Castro-Martin and Rosero-Bixby 2011) and Canada (Adserà and Ferrer 2014) and Turkish migrants in Germany (Milewski 2010) to the fact that their primary socialization occurred in contexts in which families were relatively large. Likewise, given that 
international migration requires planning, it has been argued that migrants-to-be adjust their family formation decisions based on their plans for migration. For instance, it has been posited that an individual may choose to avoid having children or to formalize an informal union with a partner before migration because childlessness and marriage facilitate emigration (Kulu 2005). Studies of fertility among migrants in the United States (Parrado 2011), Canada (Adserà and Ferrer 2014), and Sweden (Andersson 2004) have found that migrants' fertility rates tend to be lower in the years before migration, but that their birth risk peaks within five years of their arrival.

The last two explanations emphasize that changing circumstances caused by migration can disrupt migrants' family formation trajectories; but also that the living conditions at destination can prompt migrants to assimilate to the prevailing behaviors in the host society, thereby diminishing the overall impact of the initial disruption. For example, the low fertility rates observed among Mexican men after migration to the US have been linked to spousal absence, and to high fertility rates after family reunification (Lindstrom and Giorguli Saucedo 2002). Similarly, fertility among migrants to France and Italy has been shown to peak during the years following migration (Mussino and Strozza 2012; Toulemon 2004), which can distort period fertility measures, but usually changes cohort fertility only moderately (Toulemon and Mazuy 2004). Similar patterns have been reported for the marital dynamics of African and Latin American migrants in Europe (Beauchemin et al. 2015; Cortina Trilla, Esteve Palós, and Cabré Pla 2009) and for Latin American migrants in the US (Parrado 2004). This latter study showed that the marriage market conditions in the US are associated with delayed marriage and circular migration, as male Mexican migrants must go back to their region of origin to find a female partner. However, there is also evidence that migrant women are more likely than migrant men 
to marry a US-born individual, and that this probability is negatively associated with the age at arrival (Choi and Tienda 2017). These sex differences may influence the validity of the disruption and assimilation hypotheses, with the former being more likely to apply to men than to women, and the latter being more likely to apply to women than to men.

Over the life courses of individuals, these differences in the timing of family events between the native and foreign-born populations do not translate into lower completed fertility or lower marriage prevalence. Due to context-specific conditions, migrants tend to have around the same number of children as the native-born population. This pattern has been found for Hispanic migrants in the US (Parrado 2011) and migrants in the United Kingdom (Dubuc 2012). Among the potential explanations for the convergence of fertility levels between native- and foreign-born populations over time are that the cost of educating children in the destination country is higher, that migrants are exposed to positive ideas about smaller families, and that the average family size in the country of origin is also decreasing (Bean, Berg, and Van Hook 1996; Frank and Heuveline 2005). In addition, the finding that differences in fertility between migrants and nonmigrants diminish progressively across migrant generations (Kulu and González-Ferrer 2014; Pailhé 2015; Parrado and Morgan 2008) reinforces the validity of the assimilation hypotheses in the context of generational replacement.

The narratives built upon the "competition" of these four explanations describe the experiences of an "average migrant," while neglecting potential heterogeneity in the relationship between family formation and migration. In other words, because these studies mostly focused on "mean levels" of the intensity and timing of family events (e.g., first birth, age at marriage), it can be hard to grasp the complementary nature of the socialization, selection, assimilation, and disruption hypotheses. As de Hass has posited: 
“The focus on the 'representative agent' (in our case the average migrant) is reinforced by the widespread diffusion of regression analysis as the gold standard for quantitative empirical analysis and the concomitant tendency to ignore distributional issues and, more generally, power. As Garip (2012) recently argued in a powerful critique, this has also pushed migration scholars to mold questions and theories to fit the method, instead of the other way around" (De Haas 2014:8).

Even if the evidence favors one hypothesis, such as assimilation, it would be hard to assert that all migrants adopt the prevailing family behavior of the host society. Moreover, since family trajectories are not homogeneous in either the origin or the destination countries, there may be multiple socialization influences, as well as multiple forms of assimilation beyond adaptation to the family practices of the majority (e.g., Non-Hispanic whites in the US).

A theoretical solution to this puzzle is to acknowledge that these explanations are complementary, and not competing. Yet this observation alone does not add much to our understanding of how migration and family are related. Thus, to make a significant theoretical contribution to addressing this question, the drivers of this complementary relationship must be identified. My hypothesis is that the main drivers are gender and class differences in the opportunity structure of family formation (intensity and timing) and migration (when and with what resources).

For example, it is hard to imagine a middle-class migrant couple arriving during young adulthood and aspiring to stay in the US with a large number of children. Due to the high cost of education in the US, middle-class migrant couples tend to have fewer children than their nonmigrant counterparts at origin. This is even more likely to be the case if one of the partners (say, the man) was born in the US, and was thus socialized within a lower-fertility context. By contrast, fertility may be higher among low-SES couples who are pursuing a "target earner" 
migration strategy, with the spouse staying in the origin country where the cost of raising children is lower. In short, jointly considering the family practices at destination and origin and the social class backgrounds of couples suggests that migration and family formation are related in ways that depend on the migrants' sex, age at arrival, and socioeconomic status.

Capturing all these complexities requires us to have information on the childbearing, union formation, and migration histories of individuals. This type of information is not commonly available, and it has limitations, especially when it is collected retrospectively. However, combining multiple waves of the National Survey of Family Growth (NSFG) enabled me to compile a significantly large sample of US- and foreign-born people. Additionally, the NSFG collects full marital and birth histories, along with information on the year of arrival in the US for foreign-born individuals. In the next section, I describe in detail how I use this information to conduct my analysis.

\section{Data and methods}

I use five waves of the NSFG covering the period from 1995 to 2015 . The NSFG is a nationally representative survey of men and women 15 to 45 years old (More information and access to data: https://www.cdc.gov/nchs/nsfg/index.htm). I use retrospective information on individuals aged 39 and older to reconstruct their marital and birth histories (i.e., their family formation trajectories) starting at age 15 . I code the family statuses of these individuals into 16 categories that result from the combination of four marital status categories (never married, cohabiting, married, separated/divorced/widowed) and four parity levels (zero, one, two, and three or more $(3+))$. Hence, a family formation (and dissolution) trajectory is a sequence of family statuses over 25 years. 
Because the focus of the paper is on the heterogeneity of family and migration paths, I include in the analysis migrants of all origins. Small sample sizes prevent me from performing country/region-specific analysis. Moreover, this strategy allows me not only to compile a larger sample, but to incorporate all of the variability in the family formation and migration trajectories of migrants of different origins. Patterns that emerge from a very diverse sample signal robust relationships among demographic processes, and are more likely to reflect divergent relationships between family and migration (e.g., different types of assimilation).

For foreign-born individuals, I use their reported year of entry to the US (variable YRSTRUS) to calculate their age at migration. I then divide the ages at arrival into four categories: before age 18, 19 to 24,25 to 30, and after age 30. These age groups capture two important aspects of individuals' life courses. First, individuals in the first two age groups were less exposed to family norms in the country of origin than the individuals in the last two age groups. Second, the age groups capture the age schedule of family formation. The age patterns of fertility and union formation display clear peaks during young adulthood (19 to 24) among less-educated individuals, and at slightly older ages (25 to 29 ) among more-educated individuals.

I divide the US-born population into two groups. The first group is made up of Non-Hispanic white individuals (hereafter, $\mathrm{NH}$ white). The second group is made up of all other race and ethnicity groups (I use the labels "other" and "non-white" to refer to this group). While this binary distinction is insufficient to capture racial/ethnic disparities among native-born individuals, it provides a conservative reference point for understanding the significance of the differences between the family formation trajectories of native-born and foreign-born individuals. If anything, the differences between $\mathrm{NH}$ white and $\mathrm{NH}$ black US-born individuals 
(not examined here) should be larger than the differences between $\mathrm{NH}$ white people and the group defined as "other."

Hence, the primary explanatory variable of this analysis is a six-category variable that combines the two racial groups for the US-born population and the four age-at-migration groups for the foreign-born population. The six categories are NH white, other (or non-white), before age 18, 19 to 24,25 to 30 , and >30. Further disaggregation (e.g., by country of origin) is not possible due to small sample sizes, especially in the sample of men. Table 1 displays the number of individuals in each of these six categories by sex.

[Table 1 about here]

Using age 39 as a cut-off point provides a reasonable tradeoff between sample size and the completeness of family formation histories. Even though births, marriages, separations, and divorces could occur outside of this age range (i.e., before age 15 and after 39), more than $95 \%$ of these events occurred within it, which is consistent with historical evidence of family dynamics among these birth cohorts (Coontz 2014). Since the individuals in the sample were aged 39 to 45, the women were born between 1950 and 1976 and the men were born between 1958 and 1976 (the NSFG 1995 does not include men). Hence, the family lives of these birth cohorts spanned the years 1965 to 2015 , and most of their family events occurred in the second half of the $20^{\text {th }}$ century.

To compare sequences of categorical states like marital status and parity levels, it is necessary to measure the dissimilarity, or discrepancy between them. The dissimilarity between a given pair of sequences depend on five aspects of the sequences' states: (1) their frequency (2) their distribution, (3) the timing of their occurrence, (4) their duration, and (5) their sequencing 
(Studer et al. 2011). Given the correlations across these five aspects, no dissimilarity measure can account for all of them simultaneously (Studer and Ritschard 2016). Researchers need to select one approach based on the research question of interest.

I measure dissimilarity between family formation trajectories by calculating the minimum number of changes that must be made in a sequence to transform it into another sequence. For example, two changes are required to convert the series [single, single, married] into [single, married, divorced]. To make the first series identical to the second, the status "single" must be changed to "married," and the status "married" must be changed to "divorced." This minimum number of modifications is called the transformation cost. The higher the transformation cost, the greater the dissimilarity between a given pair of sequences (Abbot and Tsay 2000; Studer et al. 2011).

In my analysis, transformation costs are double-weighted to account for the divergence among states and age patterns of family formation events (Studer and Ritschard 2014). For example, changing between the "single" and "married" states should cost more than changing between the "married" and "divorced" states, because these last two states can both be considered evermarried (i.e., more similar). Likewise, a change between the "married" and "separated" states should have more weight if it occurs at a younger age because the implications of marital dissolution are more significant for younger than for older individuals. These two sets of weights are the between-state Gower's dissimilarity index and the inverse of the age-specific transition rates across states (Gower 1971; Lesnard 2010).

The between-state Grower index is a measure of between-states dissimilarity that takes into account the attributes of states that make them more different or more alike; e.g., the absence of a 
partner for "single" and "separated" women; or the fact that the "separated" and "married" statuses are "ever-married" states. I use seven attributes to compute this index: presence of a partner, ever had children, ever married, ever in a couple, currently married, fertility level, and ever transitioned to family formation. Tables A1 and A2 in the appendix display the list of attributes and the resulting dissimilarity indexes for the 16 family statuses, respectively.

Using these double-weighted transformation costs, I compute a pair-wise matrix for the individual sequences. The generic term of this matrix $\left(d_{i j}\right)$ measures the dissimilarity between the family formation trajectories of individuals $i$ and $j$. The higher this number is, the more dissimilar their family paths are. I rely on this matrix to cluster individuals with similar family trajectories by hierarchically grouping those with low values in $d_{i j}$. This classification is consolidated using the k-means algorithm over cluster solutions from two to 15 clusters (Kaufman and Rousseeuw 1990; Studer 2013). Table A3 in the appendix reports two goodnessof-fit indicators for these clusters solutions by sex. Based on this table, I select a six-cluster solution. I call this partition a "family formation typology," or a "family typology" for short (more details on the adequacy and interpretation of this cluster solution are provided in the results section).

I estimate the conditional distribution of men and women in this typology by race/ethnicity and age at migration (i.e., I compute a six-by-six cross-tabulation between the family typology and the groups defined in Table 1). Furthermore, I include an interaction with educational attainment (24 by six cross-tabulations). I call these distributions "family profiles" because they reflect each group's propensity to follow the family paths defined by the family typology. There are 48 family profiles; 24 for each sex. The most general family profile is that of the overall population of men and women; i.e., the marginal distribution of the family typology for each sex. 
To validate this approach and reduce the influence of socio-demographic conditions other than race/ethnicity and age at migration on family trajectories, I rely on multinomial logistic models (MLM). I use the AIC to assess the goodness-of-fit of different model specifications. A lower AIC indicates a better representation of the cross-tabulation between the family typology and predictor variables. The baseline specification predicts the family typology based on birth cohort. This is an appropriate baseline given the temporal patterns of change in the family practices described above. For more complex model specifications, I measure the percent change in the AIC, with negative relative changes indicating a better fit (Dobson and Barnett 2008). Although the lowest AIC is obtained when controlling for birth cohort and religious affiliation, the results do not differ substantially between specifications with and without these control variables.

The interpretation of the MLM's results is troublesome because there are six family types and 48 family profiles. To better explore the heterogeneity and patterns of these models, I have built a two-dimensional representation that applies Principal Component Analysis (PCA) to the table of predicted probabilities. The first two factorial coordinates of the PCA are used to plot the 48 family profiles along with the six family typology categories. This joint representation depicts the main associations between the explanatory variables and the family typology categories. This approach is entirely in line with the purpose of the paper; i.e., of explicitly exploring heterogeneity (rather than describing mean/marginal differences). Full tables of predicted probabilities and standard errors are included in the appendix (Table A4 for women and Table A5 for men). 


\section{Results}

Figure 1 displays the state distribution plot by race/ethnicity and age at migration for women (top) and men (bottom) in the analytical sample. These plots depict the aggregate prevalence and timing of births, and the changes in marital status over individuals' life courses (see Cornwell 2015 for an overview of these plots). Four different colors distinguish the marital statuses, and their shades are proportional to the number of children ever born, following standard visualization practices for sequence data (Fasang and Liao 2014).

Figure 1 about here

Figure 1 displays two key patterns that reflect the main characteristics of US family practices, and how they differ across social groups. First, the prevalence of marriage was remarkably high for both sexes. Regardless of the individuals' race/ethnicity or age at migration, formal marital unions were normative. By age 39, the vast majority of individuals were married or had been married at least once. The only exceptions were non-white US-born individuals, among whom the combined incidence of singlehood, single-parenthood, and cohabitation was highest. By age 39 , around $30 \%$ of these women and $15 \%$ of these men had never entered marriage. Non-white US-born individuals also displayed the highest prevalence of marital dissolution, which contrasted with the low levels observed among the foreign-born groups (small blue areas in the top-right area of the panels).

Second, the main differences between the sexes and across the race/ethnicity and age-atmigration groups were related to the timing of family formation events. Transitions to marriage and to first birth occurred later, and the birth intervals were longer among foreign-born than USborn individuals, except among those who arrived before age 18 . These patterns were especially 
pronounced for men, among whom transitions to family formation occurred later than they did among women.

The differences observed across these six groups went beyond the realm of family formation. Consistent with previous research, educational attainment and religious affiliation also varied among these groups (Hirschman 2004; Rendall and Parker 2014). Table 2 shows that the proportion of women and men with a college degree was higher among NH white than non-white individuals. This relationship held when comparing $\mathrm{NH}$ whites with individuals who migrated before age 18 .

[Table 2 about here]

For those who migrated as adults (after age 18), the highest proportions were at the two ends of the educational attainment categories. This concentration implies that the socioeconomic backgrounds of the foreign-born population were very polarized. Take, for example, women who arrived in the US between ages 25 and 30. Among these women, almost 30\% did not finish high school, whereas $32 \%$ completed college.

In terms of religious affiliation, most of the US-born individuals were Protestant (55\% among women and $45 \%$ among men), and most of the foreign-born individuals were Catholic. These differential compositions may be related to family trajectories to the extent that higher educational attainment is associated with a delayed transition to family formation and lower fertility, and religious affiliation is associated with marital stability (Furstenberg 2010).

Figure 2 displays individual family formation trajectories for women and men according to the six family typology categories. Table A3 in the appendix displays three cluster-quality indicators for cluster solutions from two to 15 . This table shows that a six-cluster solution is adequate. This 
typology accounts for $51 \%$ and $55 \%$ of the total variance of individual family trajectories for women and men, respectively. These two values are very high compared to the variance that is explained by socioeconomic and demographic variables, such as educational attainment $(6.6 \%$ for women, $3.6 \%$ for men, see a graphical representation of this in Figure 1A), religious affiliation ( $1 \%$ for women, $1.8 \%$ for men), and race and ethnicity ( $2.6 \%$ for women, $0.9 \%$ for men). For the technical details on how to computed percentages of explained variance in sequence data, see Studer et al. (2011).

I sort these six types by average completed fertility from low (bottom) to high (top), and I label each of them based on their most salient characteristic as: "never married," "delayed," "normative," "unstable," "single-parent" and "early."

[Figure 2 about here]

This typology separates family trajectories according to two criteria: (1) the number and type of family events that occurred between ages 15 and 39; and (2) their degree of proximity (similarity) to the "normative" trajectory (degree of "normativeness"). The bottom area in Figure 2 shows the family paths of delayed or no transition to family formation and low completed fertility. The upper area displays the family trajectories in which men and women started family formation early, had a large number of children, and, in some cases, formed multiple unions (blue spells within green lines). The categories of stable marriages (normative, delayed, and, to a lesser extent, early) constitute normative trajectories, whereas the nevermarried, unstable, and single-parent categories are the non-normative trajectories.

The largest shares of men (27\%) and women (29\%) belonged to the normative category - which is the main reason why it is called normative. The women and men who followed this family 
path had, on average, 2.0 and 1.9 children, respectively. Marriages in this category were stable, with only $12 \%$ of them being dissolved by age 39 ; and they started at about the same ages for both sexes. The timing, order, and number of family events (two children, one marriage) of this category correlate with positive socioeconomic outcomes for families and children, which reinforces the normative aspect of this family path (Hogan 1978; Multiple Authors 2015).

The large percentages of individuals in this category reflect the importance of marriage as a social marker in US society. Two other family path types can be considered close to normative because they were followed by large proportions of individuals, and because the prevalence of unique/stable marriages was high: early and delayed. Some $44 \%$ of women and $38 \%$ of men belonged to these two categories combined. The three remaining types were far less common and were associated with worse socioeconomic outcomes for parents and children, which reinforces the idea that they correspond to non-normative (and thus less socially rewarded) family paths.

The percent distribution of men and women in this family typology is the family profile of individuals aged 39 and older in the NSFG; i.e., the family profile of individuals living in the US between 1995 and 2015. Deviations from this profile across racial/ethnic and age-at-migration groups reflect the stratified nature of family formation trajectories (race/ethnicity) and the implications of the migration experience for these trajectories (age at migration). I estimate family profiles across these two dimensions using multinomial models.

The baseline model uses only the birth cohort as a predictor variable. This model yields an AIC of 25,222 for women and of 14,041 for men. Compared to this baseline model, a model specification with educational attainment, race/ethnicity, and age at migration produces a decline in the AIC of $10.0 \%$ for women and $6.1 \%$ for men. Likewise, the AIC for the specification that 
includes the interaction between race/ethnicity and the age at migration and educational attainment reduces the AIC by $10.1 \%$ for women and $5.9 \%$ for men. Sex differences in the AIC reduction suggest that socioeconomic characteristics have more explanatory power for the family typology of women than of men.

Table 3 presents the predicted family profiles by race/ethnicity and age at migration. The lower panel in Table 3 displays the ratio between each group's family profile and that of the NH white population of each sex. I subtracted one from these ratios to facilitate interpretation. Values above 0.3 (strong positive association) are bolded, and values below -0.3 (strong negative association) are in red.

[Table 3 about here]

Although this paper does not explore in detail racial/ethnic differences, the comparison between NH white and non-white US-born individuals serves as a conservative reference point for understanding the significance of the differences by age at migration. Among US-born individuals, differences across family profiles reflected both the stratified dimension of family trajectories and their gendered nature. Compared to NH white women, non-white women were more likely to be in non-normative paths, especially in the single-parent (ratio of 0.79 ) and unstable (ratio of 0.70) family trajectory types, both of which were associated with adverse socioeconomic outcomes for children. Among men, these associations were generally weaker, with the only exception being the unstable category.

Three overarching patterns in the deviations of family profiles by age at migration can be discerned. First, being born outside of the US was negatively associated with experiencing disrupted and/or non-traditional family trajectories. Almost all ratios for the unstable, single- 
parent, and early categories (i.e., the non-normative paths) were negative for migrants. Second, this association was weaker, or was sometimes even reversed, for the first and last age at migration groups. For example, men who migrated before age 18 were $33 \%$ more likely to be in the unstable category than NH white men. Third, associations between migration and low-order family categories varied substantially by age at arrival and sex. For example, women who migrated before age 18 were more prone to be in the never-married family formation type, whereas their male counterparts were $35 \%$ less likely to follow this trajectory. Likewise, for women, a positive association between migration and the delayed transition to family formation (delayed type) could be observed only among those who migrated after age 25, whereas a positive association was found for all men, regardless of their age at arrival.

To further explore heterogeneity across educational attainment, I estimated family profiles for the interaction term between race/ethnicity and age at migration (six groups) and educational attainment (four groups). This interaction yielded 24 family profiles by sex; i.e., a probability table with 48 rows (family profiles) and six columns (family typology), with each row adding up to one.

Figure 3 displays the main patterns across these 48 family profiles, plotting the first two factorial coordinates of a Principal Component Analysis applied to the combined probability tables of men and women (Tables A4 and A5, respectively). This representation accounts for $77 \%$ of the total variance of the 48 family profiles. The left panel corresponds to women, while the right panel corresponds to men. The center of each plot represents the mean family profile; i.e., the marginal distribution of the family typology (as presented in Figure 2). I included a line connecting educational attainment categories to highlight the educational differences, and 
background lines separated by one standard deviation to provide a glimpse of the statistical significance of the results.

[Figure 3 about here]

The interpretation of Figure 3 has two features. First, the proximity of the family typology categories implies that the predicted probabilities in these categories were simultaneously high for the same educational attainment, race/ethnicity, and age-at-migration groups. For example, the two closest family formation types were single-parent and unstable; meaning that across the 48 family profiles, the proportions of individuals in these two categories were positively correlated. The opposite was found to be the case for family formation types that were distal (e.g., early vs. never-married). This means that the group of individuals in the early category were, in general, different from the individuals in the never-married category.

Second, for the points representing the race/ethnicity, age-at-migration, and educational attainment groups, closeness to the center implied that the family profile of the group resembled the mean family profile (the observed distribution in Figure 2). The reverse indicated that the family profiles differed from the mean family profile. For example, the most distinct family profile among women compared to the mean was that of high-educated women who migrated before age 18. The family profile of this group was positively associated with the never-married and delayed categories; indeed, the percentages of women in these two trajectories were $30 \%$ and $28 \%$, respectively. These figures were considerably higher than the mean: $9.1 \%$ and $17.5 \%$, respectively. Among this same group, the proportion in the early category - the most distant category to the group - was substantially lower, at $4 \%$. 
To test the robustness and significance of this approach to represent cross-tabulations coming from a liner model, Tables A4 and A5 were replicated 500 times while accounting for the standard errors of the estimated probabilities. An overall PCA was run on a table that appended all these replications. The resulting dispersion clouds and confidence ellipses are displayed in Figure 2A, and are consistent with the following interpretation.

Figure 3 captures three phenomena. First, it shows the racial/ethnic and educational disparities in family profiles among the US-born population; i.e., the socially stratified nature of family practices in the US. Second, it points to the role of migration in compressing/lowering educational gaps in family profiles due to the strong negative association between migration and the unstable and single-parent family categories. Third, it shows the gendered nature of these two results due to the lower explanatory power of educational attainment and age at migration for men's family profiles compared to those of women (i.e., a lack of strong patterning in the distribution of family profiles among men). This difference between the sexes means that going to school (as a marker for an individual's social position) and migrating influenced more women's than men's family formation trajectories. In the following paragraphs, I discuss the details of these three phenomena.

Racial/ethnic and educational disparities: The educational disparities in family profiles among US-born NH white women were significant. Among this group, those with a college education were more likely to be in family categories characterized by low fertility and delayed transition to family formation (right side of the plot). Low-educated $\mathrm{NH}$ white women were more likely to follow family formation types characterized by higher fertility, early transition to marriage, marital instability, and single-motherhood (left side of the plot). Non-white women had smaller educational disparities (i.e., the distances across educational attainment groups were shorter than 
they were for $\mathrm{NH}$ white women), and their family profiles were associated with less traditional family categories: single-parent, unstable, and never-married. This latter association was consistent with the racial/ethnic differences in family trajectories documented by the literature on the US family context (Chen and Morgan 1991; Frank and Heuveline 2005; Parrado and Flippen 2012).

The role of migration: The family profiles of foreign-born women were spread along the vertical dimension, and the educational differences were more disrupted than in the pattern observed among US-born; meaning that educational attainment had a different association with the family profiles of migrant women than with those of native-born women. For example, unlike among US-born women, low educational attainment among migrant women was not associated with single-motherhood, or, to a lesser extent, with family instability. There is no marker representing migrant-women in the second quadrant of the plot (top-left), the quadrant that contains the single-parent and unstable categories. The only exception was that of women who migrated before age 18; i.e., those with the longest period of exposure to the US family context (often referred to as the "1.5 generation"). The percentage of women in the unstable and single-parent categories among those who arrived in the US before age 18 was between that of NH white and non-white women, signaling a confluence of assimilation and socialization (refer to Table A4).

The association between migration and family profiles also varied by age at migration. Take women who migrated before age 18 as an example. Of all groups depicted in Figure 3, these women had the largest educational disparities; meaning that the family profiles of the low- and high-educated were very different. Whereas $62 \%$ of the low-educated women were in the early category, this share was only $4 \%$ among those with a college education. This pattern resembled that of NH white US-born women. The percentages of women in the early family path among 
NH white US-born were $50 \%$ for the uneducated and $8 \%$ for those with a college degree. The corresponding values for non-white women were $27 \%$ and $13 \%$.

Among the other age-at-migration groups, the lines connecting educational categories were shorter, and the greatest differences appeared in the vertical dimension (less traditional vs. more traditional family categories). Migration at early-adult ages (19 to 24) was strongly associated with the normative and early types; meaning that the confluence of the decision to migrate and the formation of a family was associated with family stability, and reduced the differences across educational attainment groups. The last two age-at-migration groups had smaller educational disparities than those observed among NH white women. Unlike among US-born women, the family profiles of women with some college and with college education did not differ substantially (their markers appeared close to one another in Figure 3). These two groups of women were more likely to follow less intense (in terms of number of children and marriages) and less traditional family trajectories, although not to the same extent as native-born NH white women. This difference may be related to the differential value that educational credentials had for migrants than for the native-born population.

Sex differences: The patterns among men were much less clear than they were for women. Educational differences for US-born men were like those of US-born women in that the group with the most distinct family profile (compared to the mean) was the group of college-educated men. These men tended to follow family formation trajectories of low fertility, delayed family formation, and stable marriage. The other three educational levels were on the opposite side of the plot; meaning that the men in these groups were more likely to transition early to family formation, to have higher fertility, and to have less normative family trajectories. As in the case 
of women, the family profiles of migrant men were closer to stable than unstable family formation paths (top vs. bottom locations).

In terms of sex differences, migrant women displayed more similarities to their US-born counterparts than migrant men did to US-born men. Among women, all of the age-at-migration groups had a flat U-shaped pattern. These results were more indicative of assimilation to the US family system than the results for men. For example, the distribution of educational categories among migrant men did not follow that of US-born men. This mismatch came from the negative association between migration and the unstable and single-parent family formation paths. None of the markers of migrant men appeared to be close to any of these two-family categories; meaning that the migration experience for men rarely implied staying in the US as a divorced, separated, or single parent. Among women, these situations were also rare, but not to the same degree as they were among men. Instead, migrant men with the lowest level of education were associated with the early family category, regardless of their age at migration.

A potential explanation for these sex differences concerns inter-marriage propensities; i.e., the probabilities of marrying someone from a different racial/ethnic group. Table 4 presents the summary of Linear Probability Models (LPM) predicting two outcomes: (1) the percentage married to NH white (exogamy), and (2) the percentage married to an individual of the same racial/ethnic group (endogamy).

[Table 4 about here]

Racial/ethnic endogamy among NH white individuals was very high, and it was lower among women than men. Among $\mathrm{NH}$ white women, the percentage married to a $\mathrm{NH}$ white man correlated positively with educational attainment. The reverse relationship was found for men; 
i.e., the higher a man's educational attainment, the less likely he was to be married to a $\mathrm{NH}$ white woman. Compared to non-white US-born women, foreign-born women had a higher probability of being married to a NH white man. This association was found to hold across all educational levels; meaning that US-born white men were more open to marrying foreign-born women than to marrying native-born women of other racial/ethnic groups.

The percentage of women married to a $\mathrm{NH}$ white men was negatively associated with the age at arrival in the US, and was positively related to educational attainment. For women, early entry was associated with greater integration into US family systems. Consistently with previous research, this integration had several dimensions (openness to intermarriage, family acceptance of exogamy, religious beliefs, etc.), and my results highlighted two in particular (Choi and Tienda 2017). First, migrant women were more likely to marry a NH white man if they arrived as a young adult. Second, early migration implied the strengthening of the educational differences in the probability of marrying a NH white man.

Migration for men was not associated with a higher probability of marrying a NH white woman. Compared to US-born non-white men, foreign-born men were less likely to marry a NH white woman at almost all educational levels. A slight exception was men who migrated before age 18 and went to college. Among this group, the proportion married to a $\mathrm{NH}$ white woman was $44 \%$, or slightly above the percentage among non-white men with a college education (42\%). The results for men should be interpreted with care, as the estimates displayed relatively large standard errors due to the small sample size.

The results for the proportion married to someone of the same racial/ethnic group mirrored those obtained for the share married to a $\mathrm{NH}$ white individual. Women were less likely than men to 
marry someone from their same racial/ethnic group. Among foreign-born individuals, the association between educational attainment and the probability of marrying someone of the same racial/ethnic group was negative for women, and it was null for men. This relationship was the most robust and was the weakest among women who migrated before age 18 and after age 30, respectively.

\section{Conclusions and discussion}

This paper has identified six typical family trajectories among men and women who were born between 1950 and 1980, and interviewed by the National Survey of Family Growth between 1995 and 2015. Accounting for more than 50\% of the total variance across 25-year-long individual family formation trajectories, this typology describes the substantial heterogeneity and robust connection among family formation events across individuals' life courses. These family trajectory types were strongly associated with individuals' educational attainment, especially among women. Migration to the US disrupted these associations in ways that varied depending on the migrants' sex, socioeconomic background, and age at arrival.

Therefore, a variegated pattern of family profiles among migrants emerged. Interpreting these patterns and their correlates using class and gender lenses underlined the complementary nature of selection, disruption, assimilation, and socialization influences on the propensity of individuals to follow typical family paths, and added nuance to some of these explanatory narratives.

For US-born individuals, the increasing importance of schooling for positive socioeconomic outcomes and the differential access to formal education has strengthened the association between educational attainment and family trajectories (Furstenberg 2014). Individuals with a 
college education were more likely to follow family formation paths characterized by a delayed transition to marriage, significant marital stability, and low fertility than individuals with fewer years of education. At the other end of the educational scale, people without a high school diploma were more likely to experience single-parenthood and marital instability, two trajectories with negative implications for the socioeconomic conditions of both adults and their children (McLanahan and Percheski 2008; Multiple Authors 2015). This association also varied by race/ethnicity. The association between higher education and marital stability was weaker for non-white than for $\mathrm{NH}$ white women.

Migrants entered the stratified family context of the US in ways that depended jointly on their sex, educational attainment, and age at arrival. On the one hand, migrating as an adolescent (before age 18) was associated with the most substantial differences in family profiles across educational attainment levels; meaning that there were differential assimilation paths according to the socioeconomic backgrounds of migrants. Early adult migration (aged 19 to 24) was associated with normative family paths regardless of educational attainment. Finally, moving to the US at later ages was associated with delayed and less intense family formation trajectories in terms of the number of children and marriages (i.e., fewer children and a unique marriage).

These patterns were clearer for migrant women than for migrant men. Three related dynamics drove this sex difference. First, early migration to the US strengthened educational differences in family profiles. This was likely due to the more prolonged exposure to the US stratification system and the very distinct socioeconomic backgrounds of adolescent migrants: i.e., those who migrated as dependents vs. those who migrated as married adolescents (Landale and Oropesa 2007). This pattern contrasted with that of young adult migrants. Second, because marriage itself may help individuals cope with the challenges of migration, migrants tended to follow more 
normative/stable trajectories, especially when migrating as young adults (Parrado and Flippen 2005). Therefore, there was a strong negative association between moving and staying in the US, and both single-parenthood and marital instability. The extent to which return migration was driving these results remains unanswered. Third, among individuals who migrated after age 18, the family profiles of those with some college and college education were similar, and lower levels of educational attainment were not associated with an early transition to family formation and high fertility. Their lower rates of early family formation before migration likely explain why, despite their relatively low educational attainment, most migrants did not follow the trajectories of a rapid transition to family formation and high fertility.

The finding that these descriptions applied less to men than to women implies that men's family trajectories were less affected by the socioeconomic characteristics studied in this paper. To the extent that these characteristics (race and ethnicity, age at migration, educational attainment, religious affiliation, and birth cohort) reflected individuals' opportunity structures to develop their family lives, men faced fewer social constraints than women during this process (Curran and Rivero-Fuentes 2003; Kanaiaupuni 2000; Pedraza 1991). To be sure, migrant men had higher mobility during this period; meaning that they could travel back and forth, or eventually return to their origin countries, in the process of finding a partner or sustaining a family. Women, by contrast, have always had more restricted mobility, and when they have migrated, they have been more likely to stay (Massey 1987; Raley et al. 2004; Stephen and Bean 1992).

Analogous results have been documented in studies of time spent on household chores (Bittman et al. 2003; Brines 1994). According to these studies, individual socioeconomic characteristics (educational attainment and income) are more predictive of the time spent on household tasks for 
women than for men, which underlines how pervasive gender relations are, and make it possible to interpret my results in terms of gendered processes (West and Zimmerman 1987).

At the same time, men were substantially less likely than women to form a relationship with someone from a different racial and ethnic group, especially with a $\mathrm{NH}$ white partner of the opposite sex. On the whole, the socialization and disruption hypotheses explained the experiences of men better than those of women. First, men were more likely than women to marry someone from the same racial/ethnic group (potentially from the same origin country). Second, this type of marriage often involved traveling back and forth between the two countries (Parrado 2004). Periods of temporary couple separation have been found to disrupt fertility and marital schedules (Lindstrom and Giorguli Saucedo 2002; Parrado 2004).

By contrast, the assimilation and adaptation hypotheses seemed to apply more, on the whole, to the family paths of migrant women. However, the differences found by age at migration and educational attainment suggest that assimilation/adaptation into the US family system led to the strengthening of socially determined differences in the family profiles among women arriving before becoming adults, and to the weakening of these patterns among those arriving after age 25.

Finally, some caveats regarding the data and the potential venues for future research on family trajectories and migration are worth noting. Results based solely on information collected in the US, such as the NSFG, are likely to suffer from the so-called immigration bias (Beauchemin 2014). This bias in the sample could explain why features such as single-parenthood, sustained cohabitation, and unstable marriages were not prevalent among migrants, even though these three phenomena were increasing in the origin countries during the period of analysis (Liu, 
Esteve, and Treviño 2017). In the same vein, the experiences and family formation trajectories of migrants without legal status in the US were likely underrepresented in this work (Massey and Zenteno 2000). Hence, future research using transnational samples and samples that better capture the experiences of migrants with varying legal statuses have much to add to the findings presented in this paper. 


\section{References}

Abbot, Andrew and Angela Tsay. 2000. "Sequence Analysis and Optimal Matching Methods in Sociology." Sociological Methods \& Research 29(1):3-33.

Adserà, Alícia and Ana Ferrer. 2014. "The Fertility of Married Immigrant Women to Canada." International Migration Review 50(2):475-505.

Adserà, Alícia and Ana Ferrer. 2015. "Immigrants and Demography.” Pp. 315-74 in Handbook of the Economics of International Migration. Vol. 1A, edited by B. Chiswick and P. Miller. North-Holland: Elsevier.

Andersson, Gunnar. 2004. "Childbearing after Migration: Fertility Patterns of Foreign-Born Women in Sweden." International Migration Review 38(2):747-75.

Bean, Frank D., Ruth R. Berg, and Jennifer V. W. Van Hook. 1996. "Socioeconomic and Cultural Incorporation and Marital Disruption among Mexican Americans." Social Forces 75(2):593-617.

Beauchemin, Cris. 2014. "A Manifesto for Quantitative Multi-Sited Approaches to International Migration." International Migration Review 48(4):921-38.

Beauchemin, Cris, Jocelyn Nappa, Bruno Schoumaker, Pau Baizan, Amparo González-Ferrer, Kim Caarls, and Valentina Mazzucato. 2015. "Reunifying versus Living Apart Together across Borders: A Comparative Analysis of Sub-Saharan Migration to Europe." International Migration Review 49(1):173-99.

Bianchi, S. M. 2011. "Family Change and Time Allocation in American Families." The Annals of the American Academy of Political and Social Science 638(1):21-44.

Bianchi, Suzanne M. and Lynne M. Casper. 2000. “American Families.” Population Bulletin 55(4):1-44.

Bittman, Michael, Paula England, Liana Sayer, Nancy Folbre, and George Matheson. 2003. "When Does Gender Trump Money? Bargaining and Time in Household Work." American Journal of Sociology 109(1):186-214.

Bledsoe, Caroline H. 2004. "Reproduction at the Margins: Migration and Legitimacy in the New Europe.” Demographic Research 10(SUPPL. 3):87-116.

Brines, Julie. 1994. "Economic Dependency, Gender , and the Division of Labor at Home." The American Journal of Sociology 100(3):652-88.

Castles, Stehphen, Hein De Haas, and Mark J. Miller. 2014. The Age of Migration. Internation Population Movement in the Modern World. 5th ed. New York: The Guildford Press.

Castro-Martín, Teresa. 2002. "Consensual Unions in Latin America : Persistence of a Dual Nuptiality System.” Journal of Comparative Family Studies 33(1):35-55.

Castro-Martin, Teresa and Luis Rosero-Bixby. 2011. "Maternidades y Fronteras. La Fecundidad 
de Las Mujeres Inmigrantes En España.” Revista Internacional de Sociología (1):105-37.

Castro Martin, Teresa and Fatima Juarez. 1995. “The Impact of Women's Education on Fertility In Latin America: Searching for Explanations." International Family Planning Perspectives 21(2):52.

Chen, Renbao and S. Phillip Morgan. 1991. "Recent Trends in the Timing of First Births in the United States." Demography 28(4):513-33.

Choi, Kate H. and Marta Tienda. 2017. "Intermarriage and the Lifecycle Timing of Migration." International Migration Review 3(3):929-62.

Clark, Ximena, Timothy J. Hatton, and Jeffrey G. Williamson. 2003. "What Explains CrossBorder Migration in Latin America?" Discussion Paper No. 2012.

Coontz, Stephanie. 2014. Marriage, a History: How Love Conquered Marriage. 1st ed. New York: Penguin Books.

Cornwell, Benjamin. 2015. Social Sequence Analysis. 1st ed. Cambridge: Cambridge University Press.

Cortina Trilla, Clara, Albert Esteve Palós, and Anna Cabré Pla. 2009. “¿Con Quiénes Se Unen Los Latinoamericanos En España?: Respuestas a Partir de Tres Fuentes Estadísticas." Notas de Población (86):19-38.

Curran, Sara R. and Estela Rivero-Fuentes. 2003. "Engendering Migrant Networks: The Case of Mexican Migration." Demography 40(2):289-307.

Dobson, Annette J. and Adrian G. Barnett. 2008. An Introduction to Generalized Linear Models. 1st ed. New York: Chapman and Hall.

Donato, Katharine. 2010. "U.S. Migration from Latin America: Gendered Patterns and Shifts." The Annals of the American Academy of Political and Social Science 630:78-92.

Donato, Katharine M. 2010. "U.S. Migration from Latin America: Gendered Patterns and Shifts." Annals of the American Academy of Political and Social Science 630(1):78-92.

Donato, Katharine M., Jonathan Hiskey, Jorge Durand, and Douglas S. Massey. 2010. "Migration in the Americas: Mexico and Latin America in Comparative Context." The Annals of the American Academy of Political and Social Science 630(1):6-17.

Dubuc, Sylvie. 2012. "Immigration to the UK from High-Fertility Countries: Intergenerational Adaptation and Fertility Convergence." Population and Development Review 38(2):353-68.

Edmonston, Barry. 2006. Population Dynamics in Germany: The Role of Immigration and Population Momentum. Vol. 25.

Esteve, Albert and Elizabeth Florez-Paredes. 2018. "The Stability Paradox: Why Expansion of Women's Education Has Not Delayed Early Union Formation or Childbearing in Latin America." Studies in Family Planning 49(2):127-42. 
Fasang, Anette Eva and Tim Futing Liao. 2014. "Visualizing Sequences in the Social Sciences." Sociological Methods \& Research 43(4):643-76.

Foner, Nancy and Joanna Dreby. 2011. "Relations Between the Generations in Immigrant Families." Annual Review of Sociology 37.

Frank, Reanne and Patrick Heuveline. 2005. "A Crossover in Mexican and Mexican-American Fertility Rates: Evidence and Explanations for an Emerging Paradox." Demographic Research 12(4):77-104.

Furstenberg, F. F. 2013. "Transitions to Adulthood: What We Can Learn from the West." The ANNALS of the American Academy of Political and Social Science 646(1):28-41.

Furstenberg, Frank. 2010. "Diverging Development: The Not-so-Invisible Hand of Social Class in the United States." Pp. 276-94 in Families as They Really Are, edited by B. J. Risma. New York: W.W. Norton \& Company.

Furstenberg, Frank F. 2014. "Fifty Years of Family Change" edited by M. J. Carlson and D. R. Meyer. The ANNALS of the American Academy of Political and Social Science 654(1):1230 .

García, Brígida and Orlandina de Oliveira. 2011. "Family Changes and Public Policies in Latin America." Annual Review of Sociology 37(1):593-611.

Garip, Filiz. 2012. "Discovering Diverse Mechanisms of Migration: The Mexico-US Stream 1970-2000." Population and Development Review 38(3):393-433.

Garip, Filiz. 2017. On the Move: Changing Mechanisms of Mexico-U.S. Migration. 1st ed. Princeton, NJ: Princeton University Press.

Gibson, Campbell and Kay Jung. 2006. "Historical Census Statistics on the Foreign-Born Population of the United States: 1850 to 2000." U.S. Census Bureau, Population Division (Working Paper No.81).

Gower, J. C. 1971. "A General Coefficient of Similarity and Some of Its Properties.” Biometrics 27(4):857-71.

Guzmán, José, Jorge Rodríguez, Jorge Martínez, Juan Contreras, and Daniela González. 2006. "The Demography of Latin America and the Caribbean since 1950." Population-E 61(56):519-76.

De Haas, Hein. 2014. Migration Theory. Quo Vadis? 100. Oxford: International Migration Institute.

Hayford, Sarah R., Karen Benjamin Guzzo, and Pamela J. Smock. 2014. "The Decoupling of Marriage and Parenthood? Trends in the Timing of Marital First Births, 1945-2002." Journal of Marriage and Family 76(3):520-38.

Herrera, Gioconda. 2013. "Gender and International Migration: Contributions and CrossFertilizations.” Annual Review of Sociology 39(1):471-89. 
Hirschman, Charles. 2004. "The Role of Religion in the Origins and Adaptation of Immigrant Groups in the United States.” International Migration Review 38(3):1206-33.

Hogan, Dennis P. 1978. "The Variable Order of Events in the Life Course.” American Sociological Review 43(4):573.

Hondagneu-Sotelo, Pierrette. 1994. Gendered Transitions. Mexican Experiences of Immigration. 1st ed. Berkeley: University of California Press.

Kanaiaupuni, Shawn Malia. 2000. "Reframing the Migration Question : An Analysis of Men, Women, and Gender in Mexico.” Social Forces 78(4):1311-47.

Kandel, William and Douglas S. Massey. 2002. "The Culture of Mexican Migration : A Theoretical and Empirical Analysis." Social Forces 80(3):981-1004.

Kaufman, Leonard and Peter J. Rousseeuw. 1990. Finding Groups in Data: An Introduction to Cluster Analysis. New York: Wiley.

Kulu, Hill. 2005. "Migration and Fertility: Competing Hypotheses Re-Examined." European Journal of Population 21(1):51-87.

Kulu, Hill and Amparo González-Ferrer. 2014. "Family Dynamics Among Immigrants and Their Descendants in Europe: Current Research and Opportunities." European Journal of Population 30(4):411-35.

Kulu, Hill and Tina Hannemann. 2016. "Introduction to Research on Immigrant and Ethnic Minority Families in Europe.” Demographic Research 35(July):31-46.

Landale, N. and R. Oropesa. 2007. "Hispanic Familie: Stability and Change." Annual Review of Sociology 33.

Lesnard, Laurent. 2010. Setting Cost in Optimal Matching to Uncover Contemporaneous SocioTemporal Patterns. Vol. 38.

Lindstrom, David P. and Silvia Giorguli-Saucedo. 2007. "The Interrelationship of Fertility, Family Maintenance and Mexico-U.S. Migration.” Demographic Research 17:821-58.

Lindstrom, David P. and Silvia Giorguli Saucedo. 2002. "The Short-and Long-Term Effects of U.S. Migration Experience on Mexican Women's Fertility.” Social Forces 80(4):1341-68.

Liu, Chia, Albert Esteve, and Rocío Treviño. 2017. "Female-Headed Households and Living Conditions in Latin America.” World Development 90(637768):311-28.

Massey, Douglas S. 1987. "Understanding Mexican Migration to the United States." American Journal of Sociology 92(6):1372-1403.

Massey, Douglas S., Jorge Durand, and Karen A. Pren. 2014. "Explaining Undocumented Migration to the U.S.” International Migration Review 48(4):1028-61.

Massey, Douglas S. and Rene Zenteno. 2000. "A Validation of the Ethnosurvey: The Case of Mexico-US Migration.” International Migration Review 34(3):766-793. 
McLanahan, Sara and Christine Percheski. 2008. "Family Structure and the Reproduction of Inequalities." Annual Review of Sociology 34(1):257-76.

Milewski, Nadja. 2010. "Immigrant Fertility in West Germany: Is There a Socialization Effect in Transitions to Second and Third Births?” European Journal of Population 26:297-323.

Monte, Lindsay M. and Renee R. Ellis. 2014. "Fertility of Women in the United States: 2012." U.S. Census Bureau (July):1-26.

Multiple Authors. 2015. Families in an Era of Increasing Inequality. Vol. 5. First. edited by P. R. Amato, A. Booth, S. M. McHale, and J. Van Hook. Cham: Springer International Publishing.

Mussino, Eleonora and Salvatore Strozza. 2012. "The Fertility of Immigrants after Arrival: The Italian Case." Demographic Research 26:99-130.

Pailhé, Ariane. 2015. "Partnership Dynamics across Generations of Immigration in France: Structural vs. Cultural Factors." Demographic Research 33(1):451-98.

Parrado, Emilio. 2004. "International Migration and Men's Marriage in Western Mexico." Journal of Comparative Family Studies 35(1):51-71.

Parrado, Emilio A. 2011. "How High Is Hispanic/Mexican Fertility in the United States? Immigration and Tempo Considerations." Demography 48(3):395-409.

Parrado, Emilio A. and Chenoa A. Flippen. 2005. "Migration and Gender among Mexican Women.” American Sociological Review 70(4):606-32.

Parrado, Emilio A. and Chenoa A. Flippen. 2012. "Hispanic Fertility, Immigration, and Race in the Twenty-First Century." Race and Social Problems 4(1):18-30.

Parrado, Emilio A. and S. Phillip Morgan. 2008. "Intergenerational Fertility among Hispanic Women: New Evidence of Immigrant Assimilation.” Demography 45(3):651-71.

Pedraza, Silvia. 1991. "WOMEN AND MIGRATION: The Social Consequences of Gender." Annual Review of Sociology 17:303-25.

Piore, Michael J. 1979. Birds of Passage. Cambridge: Cambridge University Press.

Raley, R. Kelly, T. Elizabeth Durden, and Elizabeth Wildsmith. 2004. "Understanding MexicanAmerican Marriage Patterns Using a Life-Course Approach.” Social Science Quarterly 85(4):872-90.

Rendall, Michael and Susan Parker. 2014. "Two Decades of Negative Educational Selectivity of Mexican Migrants to the United States." Population and Development Review 40(3):42146.

Stephen, Elizabeth Hervey and Frank D. Bean. 1992. "Assimilation, Disruption and the Fertility of Mexican-Origin Women in the United States." International Migration Review 26(1):6788. 
Studer, Matthias. 2013. "WeightedCluster Library Manual: A Practical Guide to Creating Typologies of Trajectories in the Social Sciences with R.” LIVES Working Papers, 24.

Studer, Matthias and Gilbert Ritschard. 2014. A Comparative Review of Sequence Dissimilarity Measures.

Studer, Matthias and Gilbert Ritschard. 2016. "What Matters in Differences between Life Trajectories: A Comparative Review of Sequence Dissimilarity Measures." Journal of the Royal Statistical Society 179(2):481-511.

Studer, Matthias, Gilbert Ritschard, Alexis Gabadinho, and Nicolas S. Müller. 2011. "Discrepancy Analysis of State Sequences." Sociological Methods \& Research 40(3):471510.

Sullivan, Rachel. 2005. "The Age Pattern of First-Birth Rates among U.S. Women: The Bimodal 1990s." Demography 42(2):259-73.

Thornton, Arland and Linda Young-DeMarco. 2001. "Four Decades of Trends in Attitutdes Toward Family Issues in the United States:The 1960s through the 1990s." Journal of Marriage and Family 63(4):1009-37.

Torche, Florencia. 2014. "Intergenerational Mobility and Inequality: The Latin American Case." Annual Review of Sociology 40(1):619-42.

Toulemon, Laurent. 2004. “La Fécondité Des Immigrées: Nouvelles Donnéees, Nouvelle Approche." Populations \& Sociétés (400):1-4.

Toulemon, Laurent and Magali Mazuy. 2004. Comment Prendre En Compte l'âge à l'arrivée et La Durée de Séjour En France Dans La Mesure de La Fécondité Des Immigrants?

West, Candace and Don H. Zimmerman. 1987. "Doing Gender.” Gender and Society 1(2):12551. 
Table 1: Analytical sample by sex, race/ethnicity, and age at migration

\begin{tabular}{|c|c|c|c|c|c|c|c|}
\hline \multirow{3}{*}{$\operatorname{Sex}$} & \multicolumn{5}{|c|}{ Race/e thnicity and place of birth } & & \multirow{3}{*}{ Total } \\
\hline & \multicolumn{2}{|c|}{ Native-born } & \multicolumn{4}{|c|}{ Foreign-born by age at migration } & \\
\hline & NH white & Other & $<18$ & 19 to 24 & 25 to 30 & $>\mathbf{3 0}$ & \\
\hline Women & 4,264 & 2,093 & 390 & 284 & 278 & 323 & 7,632 \\
\hline Men & 2,214 & 1,137 & 272 & 160 & 156 & 183 & 4,122 \\
\hline Total & 6,478 & 3,230 & 662 & 444 & 434 & 506 & 11,754 \\
\hline
\end{tabular}

Note: The analytical sample includes individuals age 39 to 45 from five waves of the National Survey of Family Growth (1995, 2002, 2006-10, 2011-13 and 2013-15). The samples of men and women samples are independent, and information on men has been collected only since 2002 . All analyses are conducted using standardized sampling weights. 
Figure 1: State distribution of family statuses across ages for women (top) and men (bottom) by race/ethnicity and age at migration
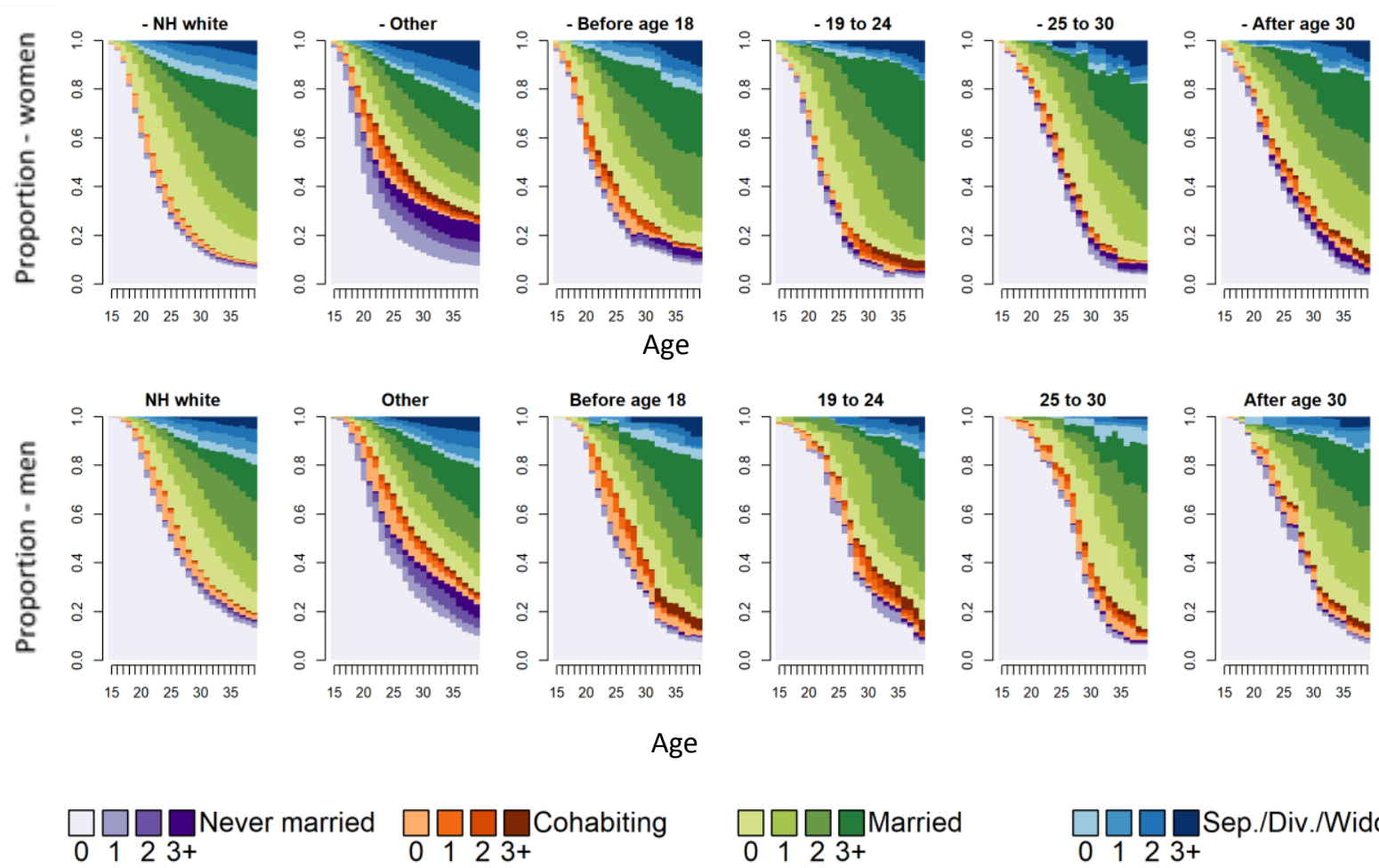

Sep./Div./Widow

Note: Figures account for sample weights. At each age from 15 to 39, the distribution of individuals across the 16 family statuses is plotted using the color code of the legend. Four colors distinguish marital status (purple: never-married, yellow: cohabiting, green: married, blue: divorced, separated, or widowed), and their shade is proportional to the number of children ever born $(0,1,2,3+)$. Interpretation: At age 15 , most individuals were single and childless. Over time (age), individuals changed their marital status and had children; the timing of these events is reflected by the boundary lines between colors (analogous to survival curves). By age 39 (righthand side of each panel), most individuals had experienced unions, marriages, births, and marital dissolution or separation; although a few never married and never had children. 
Table 2: Educational attainment and religious affiliation by sex, race/ethnicity, and age at migration

\begin{tabular}{|c|c|c|c|c|c|c|c|c|c|c|c|c|}
\hline & \multicolumn{6}{|c|}{ Women } & \multicolumn{6}{|c|}{ Men } \\
\hline & \multicolumn{2}{|c|}{ US-born } & \multicolumn{4}{|c|}{ Foreign-born by age at migration } & \multicolumn{2}{|c|}{ US-born } & \multicolumn{4}{|c|}{ Foreign-born by age at migration } \\
\hline & $\begin{array}{c}\text { NH } \\
\text { white }\end{array}$ & Other & $<18$ & $19-24$ & $25-30$ & $>\mathbf{3 0}$ & $\begin{array}{c}\text { NH } \\
\text { white }\end{array}$ & Other & $<18$ & $19-24$ & $25-30$ & $>\mathbf{3 0}$ \\
\hline \multicolumn{13}{|c|}{ Educational attainment } \\
\hline Lowest & $\begin{array}{r}10.6 \\
(0.6)\end{array}$ & $\begin{array}{r}20.7 \\
(1.3)\end{array}$ & $\begin{array}{r}29.0 \\
(3.1)\end{array}$ & $\begin{array}{r}43.0 \\
(4.5)\end{array}$ & $\begin{array}{r}29.8 \\
(3.6)\end{array}$ & $\begin{array}{r}28.9 \\
(3.4)\end{array}$ & $\begin{array}{r}12.9 \\
(1.1)\end{array}$ & $\begin{array}{r}23.1 \\
(2.1)\end{array}$ & $\begin{array}{r}39.8 \\
(4.7)\end{array}$ & $\begin{array}{r}49.8 \\
(5.4)\end{array}$ & $\begin{array}{r}27.0 \\
(5.0)\end{array}$ & $\begin{array}{r}29.0 \\
(5.1)\end{array}$ \\
\hline Low & $\begin{array}{r}27.1 \\
(1.0)\end{array}$ & $\begin{array}{r}31.3 \\
(1.4)\end{array}$ & $\begin{array}{r}21.5 \\
(2.5)\end{array}$ & $\begin{array}{r}20.1 \\
(3.3)\end{array}$ & $\begin{array}{r}21.1 \\
(3.8)\end{array}$ & $\begin{array}{r}17.6 \\
(2.7)\end{array}$ & $\begin{array}{r}26.3 \\
(1.4)\end{array}$ & $\begin{array}{r}33.4 \\
(2.2)\end{array}$ & $\begin{array}{r}21.1 \\
(3.5)\end{array}$ & $\begin{array}{r}12.3 \\
(3.5)\end{array}$ & $\begin{array}{r}14.2 \\
(2.9)\end{array}$ & $\begin{array}{r}17.5 \\
(4.0)\end{array}$ \\
\hline Med. & $\begin{array}{r}27.6 \\
(0.9)\end{array}$ & $\begin{array}{r}27.7 \\
(1.3)\end{array}$ & $\begin{array}{r}23.6 \\
(2.6)\end{array}$ & $\begin{array}{r}14.1 \\
(2.7)\end{array}$ & $\begin{array}{r}16.8 \\
(2.5)\end{array}$ & $\begin{array}{r}16.5 \\
(2.8)\end{array}$ & $\begin{array}{r}27.3 \\
(1.4)\end{array}$ & $\begin{array}{r}25.8 \\
(2.0)\end{array}$ & $\begin{array}{r}14.2 \\
(2.5)\end{array}$ & $\begin{array}{r}16.0 \\
(3.9)\end{array}$ & $\begin{array}{r}15.0 \\
(4.0)\end{array}$ & $\begin{array}{r}17.2 \\
(4.4)\end{array}$ \\
\hline High & $\begin{array}{r}34.6 \\
\text { (1.1) }\end{array}$ & $\begin{array}{r}20.3 \\
(1.3)\end{array}$ & $\begin{array}{r}25.9 \\
(3.2)\end{array}$ & $\begin{array}{r}22.8 \\
(3.6)\end{array}$ & $\begin{array}{r}32.3 \\
(3.7)\end{array}$ & $\begin{array}{r}37.1 \\
(4.1)\end{array}$ & $\begin{array}{r}33.6 \\
(1.7)\end{array}$ & $\begin{array}{r}17.8 \\
(1.8)\end{array}$ & $\begin{array}{r}24.9 \\
(3.9)\end{array}$ & $\begin{array}{r}21.8 \\
(4.8)\end{array}$ & $\begin{array}{r}43.8 \\
(5.4)\end{array}$ & $\begin{array}{r}36.3 \\
(5.2)\end{array}$ \\
\hline \multicolumn{13}{|c|}{ Religious affiliation } \\
\hline No religion & $\begin{array}{r}14.8 \\
(0.7)\end{array}$ & $\begin{array}{l}9.7 \\
(1.0)\end{array}$ & $\begin{array}{r}14.6 \\
(2.7)\end{array}$ & $\begin{array}{r}13.5 \\
(2.8)\end{array}$ & $\begin{array}{r}16.3 \\
(3.0)\end{array}$ & $\begin{array}{r}11.9 \\
(2.8)\end{array}$ & $\begin{array}{r}22.0 \\
(1.3)\end{array}$ & $\begin{array}{r}13.8 \\
(1.4)\end{array}$ & $\begin{array}{r}21.3 \\
(3.3)\end{array}$ & $\begin{array}{r}19.1 \\
(5.0)\end{array}$ & $\begin{array}{r}20.7 \\
(4.3)\end{array}$ & $\begin{array}{r}14.7 \\
(3.4)\end{array}$ \\
\hline Catholic & $\begin{array}{r}25.9 \\
\text { (1.1) }\end{array}$ & $\begin{array}{r}21.1 \\
(1.6)\end{array}$ & $\begin{array}{r}46.3 \\
(3.7)\end{array}$ & $\begin{array}{r}47.8 \\
(4.2)\end{array}$ & $\begin{array}{r}45.2 \\
(4.2)\end{array}$ & $\begin{array}{r}47.0 \\
(3.7)\end{array}$ & $\begin{array}{r}23.7 \\
(1.5)\end{array}$ & $\begin{array}{r}23.1 \\
(2.3)\end{array}$ & $\begin{array}{r}43.8 \\
(4.9)\end{array}$ & $\begin{array}{r}42.3 \\
(5.7)\end{array}$ & $\begin{array}{r}36.5 \\
(5.5)\end{array}$ & $\begin{array}{r}32.6 \\
(6.0)\end{array}$ \\
\hline Protestant & $\begin{array}{r}54.5 \\
(1.1)\end{array}$ & $\begin{array}{r}66.0 \\
(1.8)\end{array}$ & $\begin{array}{r}32.4 \\
(3.3)\end{array}$ & $\begin{array}{r}25.3 \\
(3.3)\end{array}$ & $\begin{array}{r}15.5 \\
(2.5)\end{array}$ & $\begin{array}{r}27.5 \\
(3.4)\end{array}$ & $\begin{array}{r}47.4 \\
(1.7)\end{array}$ & $\begin{array}{r}56.2 \\
(2.6)\end{array}$ & $\begin{array}{r}19.6 \\
(3.3)\end{array}$ & $\begin{array}{r}22.8 \\
(4.7)\end{array}$ & $\begin{array}{r}18.7 \\
(4.0)\end{array}$ & $\begin{array}{r}24.7 \\
(4.2)\end{array}$ \\
\hline Other & $\begin{array}{l}4.7 \\
(0.5)\end{array}$ & $\begin{array}{l}3.3 \\
(0.8)\end{array}$ & $\begin{array}{l}6.6 \\
(1.5)\end{array}$ & $\begin{array}{r}13.4 \\
(3.0)\end{array}$ & $\begin{array}{r}22.9 \\
(4.3)\end{array}$ & $\begin{array}{r}13.6 \\
(2.6)\end{array}$ & $\begin{array}{l}7.0 \\
(0.9)\end{array}$ & $\begin{array}{l}6.9 \\
(1.4)\end{array}$ & $\begin{array}{r}15.3 \\
(3.8)\end{array}$ & $\begin{array}{r}15.8 \\
(3.7)\end{array}$ & $\begin{array}{r}24.2 \\
(4.9)\end{array}$ & $\begin{array}{r}28.0 \\
(6.2)\end{array}$ \\
\hline Percent & 65.3 & 19.6 & 4.8 & 3.5 & 3.4 & 3.4 & 64.0 & 18.9 & 5.8 & 3.4 & 3.5 & 4.3 \\
\hline
\end{tabular}

Note: Educational attainment is coded as: no high school degree (lowest), high school degree (low), some college education (med.) and college education or higher (high). Standard errors, in parenthesis, are clustered within each survey wave. There are 710 clusters for women and 452 clusters for men. 
Figure 2: Individual family trajectories and family typology by sex
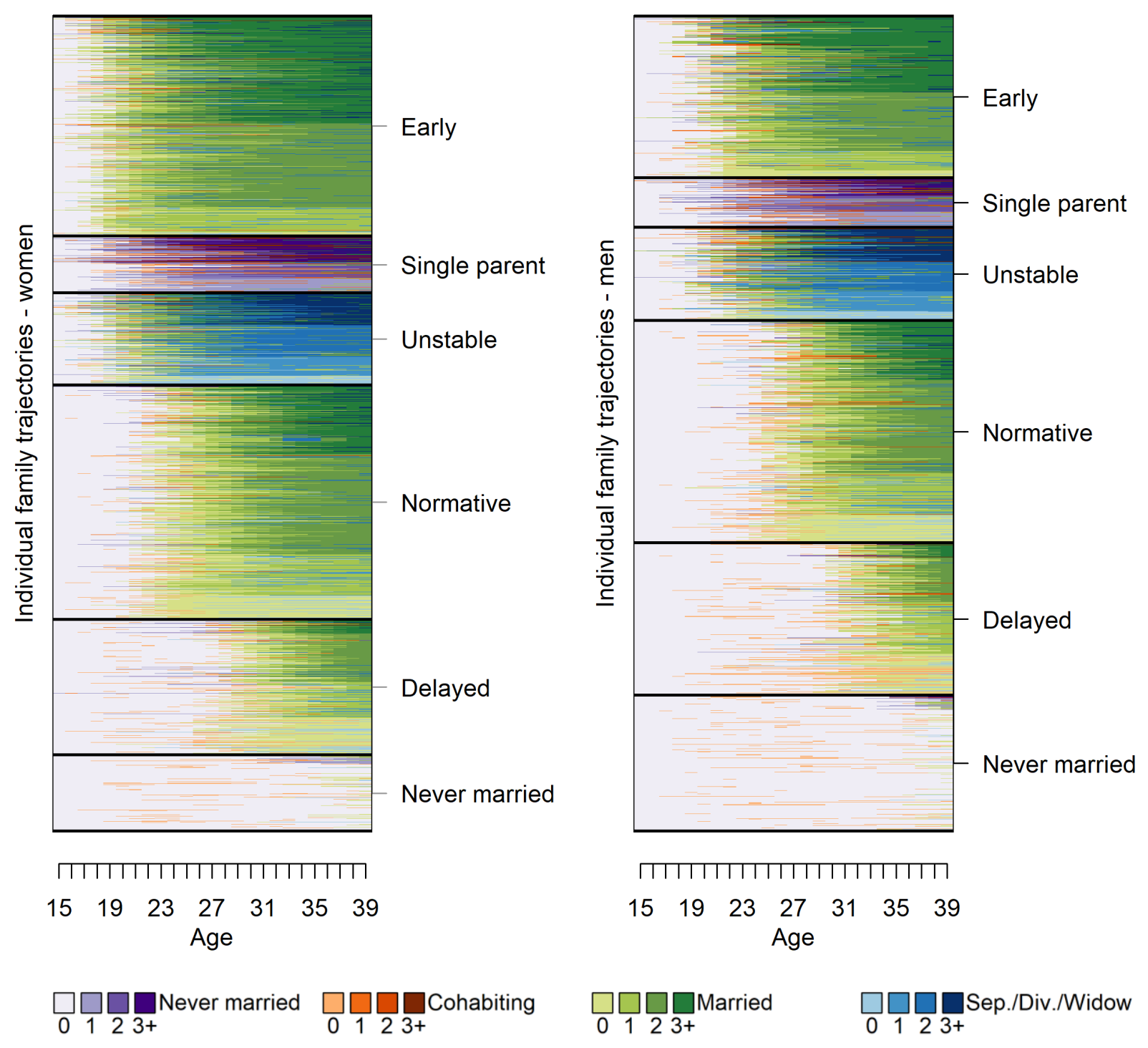

Note: Individual trajectories are sorted by complete fertility within each family category. Even though the figures account for probability sample weights, they should be interpreted with caution due to over-plotting. 
Table 3: Family profiles and deviations from NH whites' family profiles by sex, race/ethnicity, and age at migration

\begin{tabular}{|c|c|c|c|c|c|c|c|c|c|c|c|c|}
\hline \multirow[b]{2}{*}{ Groups } & \multicolumn{6}{|c|}{ Women } & \multicolumn{6}{|c|}{ Men } \\
\hline & $\begin{array}{c}\text { Never } \\
\text { married }\end{array}$ & Delayed & Norm & Unstable & $\begin{array}{l}\text { Single } \\
\text { parent }\end{array}$ & Early & $\begin{array}{c}\text { Never } \\
\text { married }\end{array}$ & Delayed & Norm & Unstable & $\begin{array}{l}\text { Single } \\
\text { parent }\end{array}$ & Early \\
\hline \multicolumn{13}{|l|}{ US-born } \\
\hline NH-white & 8.2 & 17.7 & 29.3 & 11.4 & 4.5 & 28.8 & 17.7 & 15.3 & 30.5 & 8.7 & 7.1 & 20.6 \\
\hline Other & 12.3 & 11.2 & 26.6 & 19.5 & 8.1 & 22.4 & 22.3 & 19.0 & 19.9 & 14.8 & 4.6 & 19.4 \\
\hline \multicolumn{13}{|c|}{ Foreign-born by age at migration } \\
\hline$<18$ & 13.2 & 13.0 & 28.0 & 9.7 & 3.1 & 32.9 & 11.4 & 31.8 & 29.1 & 11.6 & 2.2 & 13.8 \\
\hline 19 to 24 & 4.5 & 13.4 & 54.7 & 5.0 & 1.1 & 21.3 & 18.1 & 24.0 & 37.0 & 6.7 & 2.9 & 11.2 \\
\hline 25 to 30 & 5.8 & 27.2 & 42.5 & 5.8 & 2.9 & 15.7 & 10.5 & 29.4 & 39.5 & 7.2 & 2.4 & 11.1 \\
\hline$>30$ & 9.6 & 22.9 & 35.1 & 5.9 & 3.4 & 23.1 & 13.8 & 30.3 & 29.9 & 10.0 & 2.4 & 13.6 \\
\hline \multicolumn{13}{|c|}{ Ratio of family profiles minus one (ref: $\mathrm{NH}$-white) } \\
\hline Other & 0.49 & -0.37 & -0.09 & 0.70 & 0.79 & -0.22 & 0.26 & 0.24 & -0.35 & 0.70 & -0.35 & -0.06 \\
\hline \multicolumn{13}{|c|}{ Foreign-born by age at migration } \\
\hline$<18$ & 0.61 & -0.27 & -0.04 & -0.15 & -0.31 & 0.14 & -0.35 & 1.08 & -0.05 & 0.33 & -0.70 & -0.33 \\
\hline 19 to 24 & -0.46 & -0.24 & 0.86 & -0.56 & -0.75 & -0.26 & 0.02 & 0.57 & 0.21 & -0.23 & -0.59 & -0.45 \\
\hline 25 to 30 & -0.29 & 0.54 & 0.45 & -0.49 & -0.36 & -0.45 & -0.41 & 0.92 & 0.29 & -0.18 & -0.67 & -0.46 \\
\hline$>30$ & 0.16 & 0.29 & 0.20 & -0.48 & -0.25 & -0.20 & -0.22 & 0.98 & -0.02 & 0.14 & -0.67 & -0.34 \\
\hline
\end{tabular}

Note: Control variables include birth cohort, religious affiliation, and educational attainment. Results without control variables are equivalent. Ratios above 0.3 are bolded and ratios below 0.3 are written in red. 
Figure 3: Disruption in family profiles by sex, race/ethnicity, age at migration, and educational attainment

Women

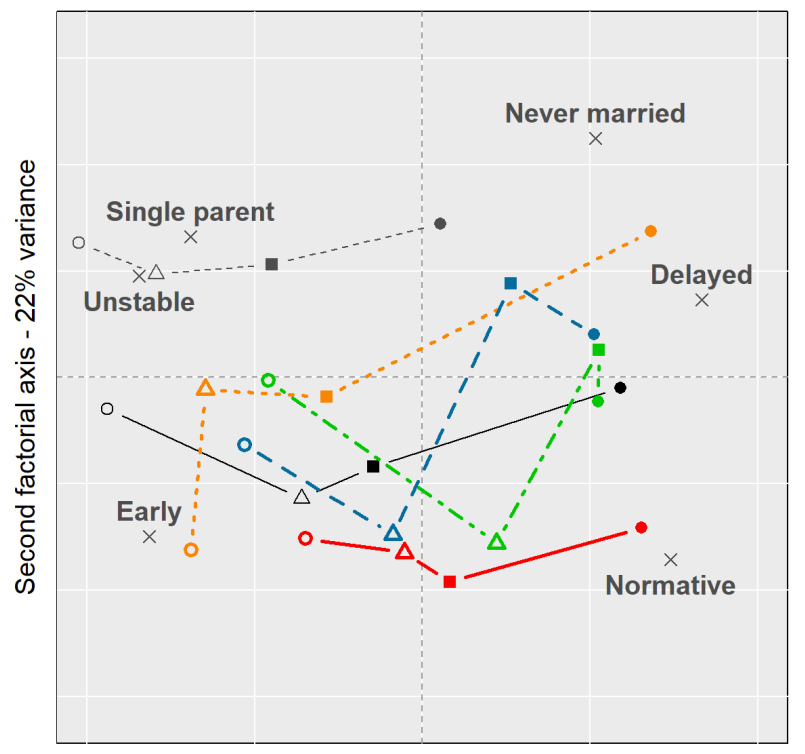

First factorial axis - 55\% variance
Men

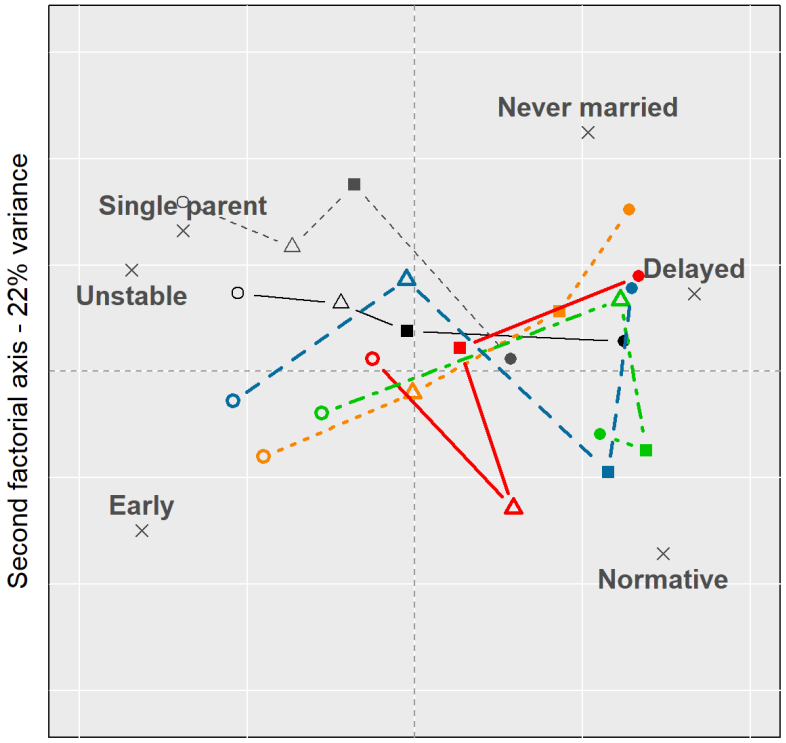

First factorial axis - 55\% variance

_ NH white _... Other - . Before age 18

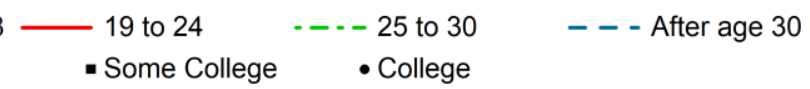

Notes: The mean profiles are (women-men): never-married (9.1\%-14.0\%), delayed (17.5\%$22.9 \%$ ), normative (28.6\%-29.6\%), unstable (9.2\%-9.9\%), single-parent (8.1\%-5.8\%), early (27.6\%-17.8\%). Background white lines are separated by one standard deviation. The $\%$ of variance of each axis refers to the total variance in Tables A4 and A5, and not to the variance of individual family trajectories. 
Table 4: Sex differences in the percent married to a NH white individual (top) and the percent married to a member of the same racial/ethnic group (bottom)

\begin{tabular}{|c|c|c|c|c|c|c|c|c|c|c|c|c|}
\hline & \multicolumn{6}{|c|}{ Women } & \multicolumn{6}{|c|}{ Men } \\
\hline & \multicolumn{2}{|c|}{ US-born } & \multicolumn{4}{|c|}{ Foreign-bonr by age at migration } & \multicolumn{2}{|c|}{ US-born } & \multicolumn{4}{|c|}{ Foreign-bonr by age at migration } \\
\hline & $\begin{array}{c}\text { NH } \\
\text { white }\end{array}$ & Other & $<18$ & 19-24 & 25-30 & $>\mathbf{3 0}$ & $\begin{array}{c}\text { NH } \\
\text { white }\end{array}$ & Other & $<18$ & 19-24 & 25-30 & $>\mathbf{3 0}$ \\
\hline \multicolumn{13}{|c|}{ Percent whose partner is NH white } \\
\hline Const. & $\begin{array}{l}85^{\text {**** }} \\
(3.2)\end{array}$ & $\begin{array}{c}18^{* *} \\
(5.8)\end{array}$ & $\begin{array}{l}71^{\text {**** }} \\
(12.2)\end{array}$ & $\begin{array}{c}36^{\text {** }} \\
(13.1)\end{array}$ & $\begin{array}{r}11 \\
(12.7)\end{array}$ & $\begin{array}{r}18 \\
(13.4)\end{array}$ & $\begin{array}{l}100^{* * * *} \\
(4.6)\end{array}$ & $\begin{array}{l}42^{\text {** }} \\
(13.7)\end{array}$ & $\begin{array}{r}15 \\
(12.0)\end{array}$ & $\begin{array}{r}13 \\
(11.2)\end{array}$ & $\begin{array}{r}-26 \\
(16.7)\end{array}$ & $\begin{array}{c}27+ \\
(15.1)\end{array}$ \\
\hline \multicolumn{13}{|c|}{ Educational attainment (Ref. Lowest) } \\
\hline Low & $6^{\text {** }}$ & $\begin{array}{r}4 \\
(2.9)\end{array}$ & $\begin{array}{c}22 \\
(9.7)\end{array}$ & $\begin{array}{l}30^{* *} \\
(9.4)\end{array}$ & $\begin{array}{c}19^{+} \\
(11.0)\end{array}$ & $\begin{array}{r}3 \\
(7.3)\end{array}$ & $\begin{array}{l}-8^{* *} \\
(2.7)\end{array}$ & $\begin{array}{r}-6 \\
(8.4)\end{array}$ & $\begin{array}{c}17+ \\
(9.8)\end{array}$ & $\begin{array}{r}-5 \\
(6.3)\end{array}$ & $\begin{array}{r}1 \\
(4.4)\end{array}$ & $\begin{array}{l}-14 \\
(9.6)\end{array}$ \\
\hline Med. & $7^{\text {*** }}$ & $\begin{array}{c}8^{*} \\
(3.3)\end{array}$ & $\begin{array}{l}25^{*} \\
(9.5)\end{array}$ & $\begin{array}{l}39^{\text {*** }} \\
(9.9)\end{array}$ & $\begin{array}{l}20^{*} \\
(9.1)\end{array}$ & $\begin{array}{l}17^{*} \\
(7.7)\end{array}$ & $\begin{array}{l}-8^{*} \\
(3.2)\end{array}$ & $\begin{array}{r}1 \\
(8.4)\end{array}$ & $\begin{array}{c}17+ \\
(10.0)\end{array}$ & $\begin{array}{r}-4 \\
(6.1)\end{array}$ & $\begin{array}{c}32+ \\
(16.4)\end{array}$ & $\begin{array}{r}-13 \\
(12.9)\end{array}$ \\
\hline High & $\begin{array}{l}8^{\text {*****}} \\
(2.4)\end{array}$ & $\begin{array}{l}18^{\text {**** }} \\
(4.7)\end{array}$ & $\begin{array}{l}31^{\text {**** }} \\
(8.3)\end{array}$ & $\begin{array}{l}32^{* * *} \\
(9.5)\end{array}$ & $\begin{array}{l}35^{\text {**** }} \\
(9.4)\end{array}$ & $\begin{array}{l}24^{*} \\
(9.9)\end{array}$ & $\begin{array}{l}-6^{* *} \\
(2.0)\end{array}$ & $\begin{array}{r}-2 \\
(8.8)\end{array}$ & $\begin{array}{l}29^{* *} \\
(9.6)\end{array}$ & $\begin{array}{c}22+ \\
(12.7)\end{array}$ & $\begin{array}{c}24 \\
(9.7)\end{array}$ & $\begin{array}{r}-3 \\
(13.5)\end{array}$ \\
\hline \multicolumn{13}{|c|}{ Percent whose partner belongs to the same racial/ethnic group } \\
\hline Const. & $\begin{array}{c}85^{+} \\
(3.2)\end{array}$ & $\begin{array}{l}83^{* * *} \\
(6.1)\end{array}$ & $\begin{array}{l}70^{* * * *} \\
(10.5)\end{array}$ & $\begin{array}{l}89^{\text {*** }} \\
(8.4)\end{array}$ & $\begin{array}{l}98^{* * * *} \\
(9.3)\end{array}$ & $\begin{array}{l}78^{\text {*** }} \\
(12.0)\end{array}$ & $\begin{array}{l}100^{* * *} \\
(4.6)\end{array}$ & $\begin{array}{c}57^{+} \\
(13.9)\end{array}$ & $\begin{array}{l}59^{* * *} \\
(18.7)\end{array}$ & $\begin{array}{r}95 \\
(6.0)\end{array}$ & $\begin{array}{l}110^{\text {**** }} \\
(13.3)\end{array}$ & $\begin{array}{c}89^{*} \\
(7.8)\end{array}$ \\
\hline \multicolumn{13}{|c|}{ Educational attainment (Ref. Lowest) } \\
\hline Low & $6^{\text {** }}$ & $\begin{array}{l}-8^{*} \\
(3.9)\end{array}$ & $\begin{array}{l}-10 \\
(6.9)\end{array}$ & $\begin{array}{l}-12+ \\
(6.1)\end{array}$ & $\begin{array}{l}-20 * \\
(8.6)\end{array}$ & $\begin{array}{r}-3 \\
(5.9)\end{array}$ & $\begin{array}{l}-8^{* *} \\
(2.7)\end{array}$ & $\begin{array}{r}6 \\
(8.5)\end{array}$ & $\begin{array}{r}-14 \\
(13.0)\end{array}$ & $\begin{array}{c}11+ \\
(6.2)\end{array}$ & $\begin{array}{r}-4 \\
(4.3)\end{array}$ & $\begin{array}{r}3 \\
(2.4)\end{array}$ \\
\hline Med. & $7^{\text {** }}$ & $\begin{array}{l}-11^{* *} \\
(3.7)\end{array}$ & $\begin{array}{l}-18^{*} \\
(7.6)\end{array}$ & $\begin{array}{l}-23^{*} \\
(9.6)\end{array}$ & $\begin{array}{r}-3 \\
(4.5)\end{array}$ & $\begin{array}{r}-7 \\
(6.8)\end{array}$ & $\begin{array}{l}-8^{*} \\
(3.2)\end{array}$ & $\begin{array}{r}1 \\
(8.2)\end{array}$ & $\begin{array}{r}-7 \\
(9.3)\end{array}$ & $\begin{array}{r}3 \\
(6.1)\end{array}$ & $\begin{array}{r}-22 \\
(16.3)\end{array}$ & $\begin{array}{r}-2 \\
(2.6)\end{array}$ \\
\hline High & $\begin{array}{l}8^{* * *} \\
(2.4)\end{array}$ & $\begin{array}{l}-20^{* * * *} \\
(4.8)\end{array}$ & $\begin{array}{l}-28^{\text {**** }} \\
(7.3)\end{array}$ & $\begin{array}{r}-4 \\
(7.4)\end{array}$ & $\begin{array}{l}-15^{+} \\
(8.1)\end{array}$ & $\begin{array}{l}-10 \\
(6.2)\end{array}$ & $\begin{array}{l}-6^{* * *} \\
(2.0)\end{array}$ & $\begin{array}{r}3 \\
(9.1)\end{array}$ & $\begin{array}{r}1 \\
(7.1)\end{array}$ & $\begin{array}{l}-12 \\
(7.5)\end{array}$ & $\begin{array}{l}-14 \\
(8.1)\end{array}$ & $\begin{array}{r}-5 \\
(3.5)\end{array}$ \\
\hline
\end{tabular}

Significance levels are presented as: $+0.1, * 0.05, * * 0.01$, and $* * * 0.001$.

Note: Control variables include birth cohort, religious affiliation, and educational attainment. Standard errors, in parenthesis, are clustered by survey wave. There are 710 clusters for women and 452 clusters for men. 


\section{Appendix}

Table A1: List of attributes for the between-state dissimilarity indexes

\begin{tabular}{|c|c|c|c|c|c|c|c|c|c|}
\hline \multicolumn{3}{|c|}{ Family status } & \multicolumn{7}{|c|}{ Attributes } \\
\hline Marital status & $\begin{array}{l}\text { Children } \\
\text { ever born }\end{array}$ & $\begin{array}{l}\text { Short label } \\
\end{array}$ & Partner? & Children? & $\begin{array}{c}\text { Ever } \\
\text { married? }\end{array}$ & $\begin{array}{c}\text { Ever in } \\
\text { couple? }\end{array}$ & $\begin{array}{l}\text { Currenlty } \\
\text { married? }\end{array}$ & $\begin{array}{c}\text { Fertility } \\
\text { level }\end{array}$ & $\begin{array}{c}\text { Ever } \\
\text { transitioned? }\end{array}$ \\
\hline \multirow{4}{*}{$\begin{array}{l}\text { Never } \\
\text { married }\end{array}$} & Zero & $\mathrm{Nm0}$ & No & No & No & No & No & None & No \\
\hline & One & $\mathrm{Nml}$ & No & Yes & No & No & No & Low & Yes \\
\hline & Two & $\mathrm{Nm} 2$ & No & Yes & No & No & No & Medium & Yes \\
\hline & Three+ & $\mathrm{Nm} 3+$ & No & Yes & No & No & No & High & Yes \\
\hline \multirow[t]{4}{*}{ Cohabiting } & Zero & $\mathrm{Co} 0$ & Yes & No & No & Yes & No & None & Yes \\
\hline & One & Co1 & Yes & Yes & No & Yes & No & Low & Yes \\
\hline & Two & $\mathrm{Co} 2$ & Yes & Yes & No & Yes & No & Medium & Yes \\
\hline & Three+ & $\mathrm{Co} 3+$ & Yes & Yes & No & Yes & No & High & Yes \\
\hline \multirow[t]{4}{*}{ Married } & Zero & $\mathrm{Ma0}$ & Yes & No & Yes & Yes & Yes & None & Yes \\
\hline & One & Ma1 & Yes & Yes & Yes & Yes & Yes & Low & Yes \\
\hline & Two & $\mathrm{Ma} 2$ & Yes & Yes & Yes & Yes & Yes & Medium & Yes \\
\hline & Three+ & Ma3+ & Yes & Yes & Yes & Yes & Yes & High & Yes \\
\hline \multirow{4}{*}{$\begin{array}{l}\text { Separated, } \\
\text { Divorced } \\
\text { and Widow }\end{array}$} & Zero & $\mathrm{Se} 0$ & No & No & Yes & Yes & No & None & Yes \\
\hline & One & $\mathrm{Se} 1$ & No & Yes & Yes & Yes & No & Low & Yes \\
\hline & Two & $\mathrm{Se} 2$ & No & Yes & Yes & Yes & No & Medium & Yes \\
\hline & Three+ & $\mathrm{Se} 3+$ & No & Yes & Yes & Yes & No & High & Yes \\
\hline
\end{tabular}

Note: These attributes are used to compute the between-state dissimilarity indexes based on Gower's (1971) work. 
Table A2: Between-state dissimilarity indexes

\begin{tabular}{|c|c|c|c|c|c|c|c|c|c|c|c|c|c|c|c|}
\hline & & & & & & & Fam & nily statu & uses & & & & & & \\
\hline & Nm0 & Nm1 & Nm2 & Nm3+ & CoO & Co1 & $\mathrm{Co2}$ & $\mathrm{Co3}+$ & Ma0 & Ma1 & Ma2 & Ma3+ & SeO & Se1 & $\mathrm{Se} 2$ \\
\hline Nm0 & & & & & & & & & & & & & & & \\
\hline Nm1 & 0.33 & & & & & & & & & & & & & & \\
\hline $\mathrm{Nm} 2$ & 0.38 & 0.05 & & & & & & & & & & & & & \\
\hline Nm3+ & 0.43 & 0.10 & 0.05 & & & & & & & & & & & & \\
\hline CoO & 0.43 & 0.48 & 0.52 & 0.57 & & & & & & & & & & & \\
\hline Co1 & 0.62 & 0.29 & 0.33 & 0.38 & 0.19 & & & & & & & & & & \\
\hline $\mathrm{Co} 2$ & 0.67 & 0.33 & 0.29 & 0.33 & 0.24 & 0.05 & & & & & & & & & \\
\hline Co3+ & 0.71 & 0.38 & 0.33 & 0.29 & 0.29 & 0.10 & 0.05 & & & & & & & & \\
\hline Ma0 & 0.71 & 0.76 & 0.81 & 0.86 & 0.29 & 0.48 & 0.52 & 0.57 & & & & & & & \\
\hline Ma1 & 0.91 & 0.57 & 0.62 & 0.67 & 0.48 & 0.29 & 0.33 & 0.38 & 0.19 & & & & & & \\
\hline Ma2 & 0.95 & 0.62 & 0.57 & 0.62 & 0.52 & 0.33 & 0.29 & 0.33 & 0.24 & 0.05 & & & & & \\
\hline Ma3+ & 1.00 & 0.67 & 0.62 & 0.57 & 0.57 & 0.38 & 0.33 & 0.29 & 0.29 & 0.10 & 0.05 & & & & \\
\hline SeO & 0.43 & 0.48 & 0.52 & 0.57 & 0.29 & 0.48 & 0.52 & 0.57 & 0.29 & 0.48 & 0.52 & 0.57 & & & \\
\hline Se1 & 0.62 & 0.29 & 0.33 & 0.38 & 0.48 & 0.29 & 0.33 & 0.38 & 0.48 & 0.29 & 0.33 & 0.38 & 0.19 & & \\
\hline $\mathrm{Se} 2$ & 0.67 & 0.33 & 0.29 & 0.33 & 0.52 & 0.33 & 0.29 & 0.33 & 0.52 & 0.33 & 0.29 & 0.33 & 0.24 & 0.05 & \\
\hline Se3+ & 0.71 & 0.38 & 0.33 & 0.29 & 0.57 & 0.38 & 0.33 & 0.29 & 0.57 & 0.38 & 0.33 & 0.29 & 0.29 & 0.10 & 0.05 \\
\hline
\end{tabular}

Note: Marital statuses are coded as: never-married (Nm); cohabiting (Co); married (Ma); divorced, separated, or widowed (Se). To obtain final transformation costs, these dissimilarity indexes are combined with age-specific between-state transition rates. Age-specific transition rates are available upon request. Interpretation: In the first column, the $\mathbf{N m 0}$ and $\mathbf{M a 3}+$ states are maximally dissimilar (dissimilarity $=1.00$ ) because they differ in all seven attributes. By contrast, Nm0 and $\mathbf{N m 1}$ differ only in the number of children ever born (0 vs. 1), and this difference is small; hence, the dissimilarity between these two states is 0.33 . 
Table A3: Cluster quality indicators for family formation trajectories by sex

\begin{tabular}{ccccccc}
\hline \multirow{2}{*}{$\begin{array}{c}\text { Number of } \\
\text { clusters }\end{array}$} & \multicolumn{3}{c}{ Women } & \multicolumn{3}{c}{ Men } \\
\cline { 2 - 7 } & ASW & R2 & R2sq & ASW & R2 & R2sq \\
\hline 2 & 0.383 & 0.248 & 0.444 & 0.446 & 0.291 & 0.493 \\
3 & 0.341 & 0.368 & 0.605 & 0.364 & 0.412 & 0.648 \\
4 & 0.330 & 0.421 & 0.663 & 0.352 & 0.467 & 0.703 \\
5 & 0.305 & 0.474 & 0.719 & 0.316 & 0.512 & 0.743 \\
6 & 0.320 & 0.514 & 0.760 & 0.345 & 0.550 & 0.786 \\
7 & 0.276 & 0.540 & 0.782 & 0.322 & 0.575 & 0.803 \\
8 & 0.299 & 0.569 & 0.809 & 0.339 & 0.603 & 0.829 \\
9 & 0.263 & 0.583 & 0.817 & 0.313 & 0.616 & 0.839 \\
10 & 0.278 & 0.596 & 0.829 & 0.298 & 0.628 & 0.846 \\
11 & 0.254 & 0.609 & 0.835 & 0.303 & 0.638 & 0.853 \\
12 & 0.262 & 0.621 & 0.846 & 0.308 & 0.647 & 0.860 \\
13 & 0.269 & 0.629 & 0.854 & 0.285 & 0.653 & 0.864 \\
14 & 0.264 & 0.639 & 0.860 & 0.280 & 0.657 & 0.866 \\
15 & 0.259 & 0.646 & 0.866 & 0.285 & 0.666 & 0.874 \\
\hline
\end{tabular}

Note: For the three indicators, positive high values indicate a better cluster solution. ASW (Average Silhouette Width) measures clusters consistency and it is not monotonic; R2 is a pseudo- $\mathrm{R}^{2}$ measure that captures the share of the discrepancy explained by the clustering solution; R2sq is like R2, but is based on the square of the distances. Refer to Studer (2013) for a full description of these indicators. 


\section{Figure 1A: Individual family trajectories by educational attainment and sex}
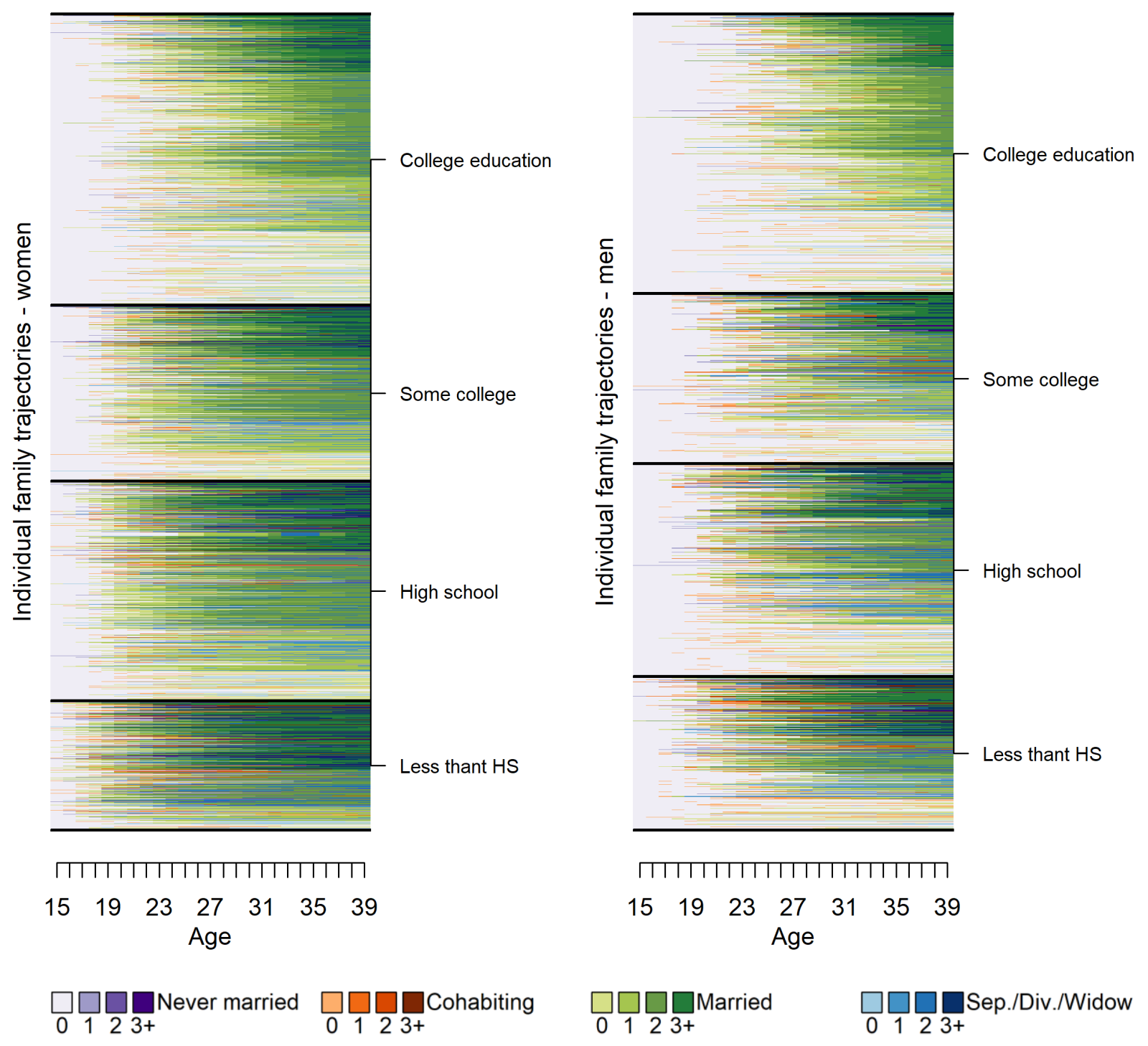

$\underset{0}{\square} \square \frac{1}{2} \square_{3+}$ Sep./Div./Widow

Note: Individual trajectories are sorted by completed fertility within each educational category. Even though the figures account for probability sample weights, they should be interpreted with caution due to over-plotting. 
Table A4: Predicted probabilities for family profiles of women

\begin{tabular}{|c|c|c|c|c|c|c|c|c|}
\hline \multirow{2}{*}{$\begin{array}{l}\text { Race/ethnicity and } \\
\text { age at migration }\end{array}$} & \multirow{2}{*}{$\begin{array}{c}\text { Educ. } \\
\text { Attainment }\end{array}$} & \multicolumn{6}{|c|}{ Family typology } & \multirow[b]{2}{*}{ Total } \\
\hline & & $\begin{array}{c}\text { Never } \\
\text { married }\end{array}$ & Delayed & Normative & Unstable & $\begin{array}{l}\text { Single } \\
\text { parent }\end{array}$ & Early & \\
\hline \multicolumn{9}{|l|}{ US-born } \\
\hline \multirow[t]{4}{*}{ NH white } & Lowest & $\begin{array}{l}4.1 \\
(0.9)\end{array}$ & $\begin{array}{l}5.1 \\
(1.0)\end{array}$ & $\begin{array}{r}10.6 \\
(1.3)\end{array}$ & $\begin{array}{r}23.9 \\
(1.9)\end{array}$ & $\begin{array}{l}7.0 \\
(1.1)\end{array}$ & $\begin{array}{r}49.4 \\
(2.2)\end{array}$ & 100.0 \\
\hline & Low & $\begin{array}{l}5.1 \\
(0.6)\end{array}$ & $\begin{array}{r}10.2 \\
(0.8)\end{array}$ & $\begin{array}{r}27.8 \\
(1.2)\end{array}$ & $\begin{array}{r}12.9 \\
(0.9)\end{array}$ & $\begin{array}{l}2.5 \\
(0.4)\end{array}$ & $\begin{array}{r}41.5 \\
(1.3)\end{array}$ & 100.0 \\
\hline & Medium & $\begin{array}{l}7.5 \\
(0.7)\end{array}$ & $\begin{array}{r}13.8 \\
(0.9)\end{array}$ & $\begin{array}{r}32.5 \\
(1.3)\end{array}$ & $\begin{array}{r}12.4 \\
(0.9)\end{array}$ & $\begin{array}{l}2.3 \\
(0.4)\end{array}$ & $\begin{array}{r}31.5 \\
(1.3)\end{array}$ & 100.0 \\
\hline & High & $\begin{array}{r}14.8 \\
(0.9)\end{array}$ & $\begin{array}{r}31.0 \\
(1.1)\end{array}$ & $\begin{array}{r}41.2 \\
(1.2)\end{array}$ & $\begin{array}{l}4.1 \\
(0.5)\end{array}$ & $\begin{array}{l}0.9 \\
(0.2)\end{array}$ & $\begin{array}{l}8.1 \\
(0.7)\end{array}$ & 100.0 \\
\hline \multirow[t]{4}{*}{ Other } & Lowest & $\begin{array}{c}3.9 \\
(1.1)\end{array}$ & $\begin{array}{l}6.1 \\
(1.4)\end{array}$ & $\begin{array}{c}9.9 \\
(1.7)\end{array}$ & $\begin{array}{r}19.2 \\
(2.2)\end{array}$ & $\begin{array}{r}33.7 \\
(2.7)\end{array}$ & $\begin{array}{r}27.1 \\
(2.5)\end{array}$ & 100.0 \\
\hline & Low & $\begin{array}{l}8.3 \\
(1.3)\end{array}$ & $\begin{array}{l}5.9 \\
(1.1)\end{array}$ & $\begin{array}{r}13.6 \\
(1.6)\end{array}$ & $\begin{array}{r}15.0 \\
(1.7)\end{array}$ & $\begin{array}{r}27.4 \\
(2.1)\end{array}$ & $\begin{array}{r}29.8 \\
(2.1)\end{array}$ & 100.0 \\
\hline & Medium & $\begin{array}{r}10.8 \\
(1.5)\end{array}$ & $\begin{array}{r}12.2 \\
(1.6)\end{array}$ & $\begin{array}{r}23.4 \\
(2.1)\end{array}$ & $\begin{array}{r}19.6 \\
(2.0)\end{array}$ & $\begin{array}{r}18.6 \\
(1.9)\end{array}$ & $\begin{array}{r}15.5 \\
(1.8)\end{array}$ & 100.0 \\
\hline & High & $\begin{array}{r}22.0 \\
(2.4)\end{array}$ & $\begin{array}{r}18.7 \\
(2.2)\end{array}$ & $\begin{array}{r}24.3 \\
(2.5)\end{array}$ & $\begin{array}{r}10.2 \\
(1.7)\end{array}$ & $\begin{array}{r}12.2 \\
(1.9)\end{array}$ & $\begin{array}{r}12.6 \\
(1.9)\end{array}$ & 100.0 \\
\hline \multicolumn{9}{|c|}{ Foreign-born by age at migration } \\
\hline \multirow[t]{4}{*}{$<18$} & Lowest & $\begin{array}{l}1.5 \\
(1.2)\end{array}$ & $\begin{array}{l}5.5 \\
(2.2)\end{array}$ & $\begin{array}{r}16.6 \\
(3.6)\end{array}$ & $\begin{array}{l}7.5 \\
(2.6)\end{array}$ & $\begin{array}{l}6.7 \\
(2.4)\end{array}$ & $\begin{array}{r}62.2 \\
(4.7)\end{array}$ & 100.0 \\
\hline & Low & $\begin{array}{l}7.5 \\
(3.0)\end{array}$ & $\begin{array}{l}6.4 \\
(2.8)\end{array}$ & $\begin{array}{r}18.2 \\
(4.4)\end{array}$ & $\begin{array}{r}16.1 \\
(4.2)\end{array}$ & $\begin{array}{r}12.0 \\
(3.7)\end{array}$ & $\begin{array}{r}39.8 \\
(5.5)\end{array}$ & 100.0 \\
\hline & Medium & $\begin{array}{r}13.6 \\
(3.7)\end{array}$ & $\begin{array}{r}11.9 \\
(3.5)\end{array}$ & $\begin{array}{r}19.8 \\
(4.3)\end{array}$ & $\begin{array}{r}10.5 \\
(3.3)\end{array}$ & $\begin{array}{l}3.8 \\
(2.1)\end{array}$ & $\begin{array}{r}40.3 \\
(5.3)\end{array}$ & 100.0 \\
\hline & High & $\begin{array}{r}29.9 \\
(4.7)\end{array}$ & $\begin{array}{r}27.8 \\
(4.6)\end{array}$ & $\begin{array}{r}33.3 \\
(4.9)\end{array}$ & $\begin{array}{l}4.0 \\
(2.0)\end{array}$ & $\begin{array}{l}0.8 \\
(0.9)\end{array}$ & $\begin{array}{l}4.1 \\
(2.0)\end{array}$ & 100.0 \\
\hline \multirow[t]{4}{*}{19 to 24} & Lowest & $\begin{array}{l}1.8 \\
(1.2)\end{array}$ & $\begin{array}{r}11.6 \\
(3.0)\end{array}$ & $\begin{array}{r}28.5 \\
(4.2)\end{array}$ & $\begin{array}{l}8.5 \\
(2.6)\end{array}$ & $\begin{array}{l}5.0 \\
(2.0)\end{array}$ & $\begin{array}{r}44.6 \\
(4.6)\end{array}$ & 100.0 \\
\hline & Low & $\begin{array}{l}6.0 \\
(3.2)\end{array}$ & $\begin{array}{l}6.2 \\
(3.3)\end{array}$ & $\begin{array}{r}45.0 \\
(6.8)\end{array}$ & $\begin{array}{l}8.8 \\
(3.8)\end{array}$ & $\begin{array}{l}2.2 \\
(2.0)\end{array}$ & $\begin{array}{r}31.8 \\
(6.3)\end{array}$ & 100.0 \\
\hline & Medium & $\begin{array}{l}5.4 \\
(3.7)\end{array}$ & $\begin{array}{l}9.6 \\
(4.8)\end{array}$ & $\begin{array}{r}46.4 \\
(8.1)\end{array}$ & $\begin{array}{l}4.2 \\
(3.2)\end{array}$ & $\begin{array}{l}1.4 \\
(1.9)\end{array}$ & $\begin{array}{r}33.0 \\
(7.6)\end{array}$ & 100.0 \\
\hline & High & $\begin{array}{l}7.8 \\
(3.4)\end{array}$ & $\begin{array}{r}24.5 \\
(5.5)\end{array}$ & $\begin{array}{r}56.8 \\
(6.3)\end{array}$ & $\begin{array}{l}0.6 \\
(1.0)\end{array}$ & $\begin{array}{l}1.1 \\
(1.4)\end{array}$ & $\begin{array}{c}9.1 \\
(3.7)\end{array}$ & 100.0 \\
\hline \multirow[t]{4}{*}{25 to 30} & Lowest & $\begin{array}{l}2.8 \\
(1.9)\end{array}$ & $\begin{array}{r}15.2 \\
(4.1)\end{array}$ & $\begin{array}{r}23.9 \\
(4.9)\end{array}$ & $\begin{array}{r}12.1 \\
(3.7)\end{array}$ & $\begin{array}{r}19.5 \\
(4.5)\end{array}$ & $\begin{array}{r}26.6 \\
(5.0)\end{array}$ & 100.0 \\
\hline & Low & $\begin{array}{l}3.4 \\
(2.4)\end{array}$ & $\begin{array}{r}25.6 \\
(5.9)\end{array}$ & $\begin{array}{r}37.7 \\
(6.6)\end{array}$ & $\begin{array}{l}1.5 \\
(1.7)\end{array}$ & $\begin{array}{l}1.3 \\
(1.5)\end{array}$ & $\begin{array}{r}30.5 \\
(6.2)\end{array}$ & 100.0 \\
\hline & Medium & $\begin{array}{r}16.2 \\
(5.6)\end{array}$ & $\begin{array}{r}34.4 \\
(7.2)\end{array}$ & $\begin{array}{r}32.3 \\
(7.1)\end{array}$ & $\begin{array}{l}3.2 \\
(2.7)\end{array}$ & $\begin{array}{l}1.5 \\
(1.8)\end{array}$ & $\begin{array}{r}12.4 \\
(5.0)\end{array}$ & 100.0 \\
\hline & High & $\begin{array}{c}8.0 \\
(3.0)\end{array}$ & $\begin{array}{r}39.9 \\
(5.4)\end{array}$ & $\begin{array}{r}36.1 \\
(5.3)\end{array}$ & $\begin{array}{l}4.2 \\
(2.2)\end{array}$ & $\begin{array}{l}2.9 \\
(1.8)\end{array}$ & $\begin{array}{r}8.9 \\
(3.1)\end{array}$ & 100.0 \\
\hline \multirow[t]{4}{*}{$>30$} & Lowest & $\begin{array}{l}2.8 \\
(1.9)\end{array}$ & $\begin{array}{r}12.5 \\
(3.8)\end{array}$ & $\begin{array}{r}19.5 \\
(4.5)\end{array}$ & $\begin{array}{l}9.2 \\
(3.3)\end{array}$ & $\begin{array}{r}14.0 \\
(4.0)\end{array}$ & $\begin{array}{r}42.0 \\
(5.7)\end{array}$ & 100.0 \\
\hline & Low & $\begin{array}{c}0.9 \\
(1.4)\end{array}$ & $\begin{array}{r}14.8 \\
(5.2)\end{array}$ & $\begin{array}{r}40.1 \\
(7.2)\end{array}$ & $\begin{array}{c}6.8 \\
(3.7)\end{array}$ & $\begin{array}{c}8.2 \\
(4.0)\end{array}$ & $\begin{array}{r}29.2 \\
(6.7)\end{array}$ & 100.0 \\
\hline & Medium & $\begin{array}{r}15.4 \\
(5.5)\end{array}$ & $\begin{array}{r}35.2 \\
(7.3)\end{array}$ & $\begin{array}{r}21.0 \\
(6.2)\end{array}$ & $\begin{array}{l}4.8 \\
(3.2)\end{array}$ & $\begin{array}{l}8.3 \\
(4.2)\end{array}$ & $\begin{array}{r}15.2 \\
(5.5)\end{array}$ & 100.0 \\
\hline & High & $\begin{array}{r}18.1 \\
(3.9)\end{array}$ & $\begin{array}{r}35.0 \\
(4.8)\end{array}$ & $\begin{array}{r}27.8 \\
(4.5)\end{array}$ & $\begin{array}{l}1.6 \\
(1.3)\end{array}$ & $\begin{array}{l}1.2 \\
(1.1)\end{array}$ & $\begin{array}{r}16.2 \\
(3.7)\end{array}$ & 100.0 \\
\hline Mean family profile & & 9.1 & 17.5 & 28.6 & 9.2 & 8.1 & 27.6 & 100.0 \\
\hline
\end{tabular}

Note: Standard errors in parenthesis. This table is graphically summarized in Figures 3 and 2A. 
Table A5: Predicted probabilities for family profiles of men

\begin{tabular}{|c|c|c|c|c|c|c|c|c|}
\hline \multirow{2}{*}{$\begin{array}{l}\text { Rsce/ethnicity and } \\
\text { age at migration }\end{array}$} & \multirow{2}{*}{$\begin{array}{c}\text { Educ. } \\
\text { Attainment }\end{array}$} & \multicolumn{6}{|c|}{ Family typology } & \multirow[b]{2}{*}{ Total } \\
\hline & & $\begin{array}{c}\text { Never } \\
\text { married }\end{array}$ & Delayed & Normative & Unstable & $\begin{array}{l}\text { Single } \\
\text { parent }\end{array}$ & Early & \\
\hline \multicolumn{9}{|l|}{ US-born } \\
\hline \multirow[t]{4}{*}{ NH white } & Lowest & $\begin{array}{r}16.0 \\
(2.0)\end{array}$ & $\begin{array}{l}7.5 \\
(1.4)\end{array}$ & $\begin{array}{r}16.3 \\
(2.0)\end{array}$ & $\begin{array}{r}22.3 \\
(2.3)\end{array}$ & $\begin{array}{l}5.4 \\
(1.2)\end{array}$ & $\begin{array}{r}32.5 \\
(2.5)\end{array}$ & 100.0 \\
\hline & Low & $\begin{array}{r}16.2 \\
(1.4)\end{array}$ & $\begin{array}{r}15.5 \\
(1.4)\end{array}$ & $\begin{array}{r}20.6 \\
(1.5)\end{array}$ & $\begin{array}{r}16.2 \\
(1.4)\end{array}$ & $\begin{array}{l}5.0 \\
(0.8)\end{array}$ & $\begin{array}{r}26.6 \\
(1.7)\end{array}$ & 100.0 \\
\hline & Medium & $\begin{array}{r}16.6 \\
(1.4)\end{array}$ & $\begin{array}{r}15.4 \\
(1.3)\end{array}$ & $\begin{array}{r}28.8 \\
(1.7)\end{array}$ & $\begin{array}{r}12.6 \\
(1.2)\end{array}$ & $\begin{array}{l}5.0 \\
(0.8)\end{array}$ & $\begin{array}{r}21.6 \\
(1.5)\end{array}$ & 100.0 \\
\hline & High & $\begin{array}{r}21.2 \\
(1.4)\end{array}$ & $\begin{array}{r}26.2 \\
(1.5)\end{array}$ & $\begin{array}{r}40.2 \\
(1.6)\end{array}$ & $\begin{array}{l}2.5 \\
(0.5)\end{array}$ & $\begin{array}{l}1.1 \\
(0.3)\end{array}$ & $\begin{array}{l}8.8 \\
(1.0)\end{array}$ & 100.0 \\
\hline \multirow[t]{4}{*}{ Other } & Lowest & $\begin{array}{r}13.3 \\
(2.5)\end{array}$ & $\begin{array}{r}11.0 \\
(2.3)\end{array}$ & $\begin{array}{r}10.0 \\
(2.2)\end{array}$ & $\begin{array}{r}21.1 \\
(3.0)\end{array}$ & $\begin{array}{r}20.0 \\
(3.0)\end{array}$ & $\begin{array}{r}24.6 \\
(3.2)\end{array}$ & 100.0 \\
\hline & Low & $\begin{array}{r}16.8 \\
(2.3)\end{array}$ & $\begin{array}{r}10.5 \\
(1.9)\end{array}$ & $\begin{array}{r}18.5 \\
(2.4)\end{array}$ & $\begin{array}{r}12.2 \\
(2.0)\end{array}$ & $\begin{array}{r}18.0 \\
(2.4)\end{array}$ & $\begin{array}{r}23.8 \\
(2.6)\end{array}$ & 100.0 \\
\hline & Medium & $\begin{array}{r}23.3 \\
(3.0)\end{array}$ & $\begin{array}{r}13.3 \\
(2.4)\end{array}$ & $\begin{array}{r}18.6 \\
(2.7)\end{array}$ & $\begin{array}{r}13.9 \\
(2.4)\end{array}$ & $\begin{array}{r}14.0 \\
(2.4)\end{array}$ & $\begin{array}{r}17.0 \\
(2.7)\end{array}$ & 100.0 \\
\hline & High & $\begin{array}{r}15.1 \\
(3.0)\end{array}$ & $\begin{array}{r}26.2 \\
(3.7)\end{array}$ & $\begin{array}{r}30.6 \\
(3.9)\end{array}$ & $\begin{array}{l}4.1 \\
(1.7)\end{array}$ & $\begin{array}{l}4.9 \\
(1.8)\end{array}$ & $\begin{array}{r}19.1 \\
(3.3)\end{array}$ & 100.0 \\
\hline \multicolumn{9}{|c|}{ Foreign-born by age at migration } \\
\hline \multirow[t]{4}{*}{$<18$} & Lowest & $\begin{array}{l}3.1 \\
(1.8)\end{array}$ & $\begin{array}{l}9.2 \\
(3.0)\end{array}$ & $\begin{array}{r}28.9 \\
(4.6)\end{array}$ & $\begin{array}{r}14.4 \\
(3.6)\end{array}$ & $\begin{array}{l}9.8 \\
(3.0)\end{array}$ & $\begin{array}{r}34.6 \\
(4.9)\end{array}$ & 100.0 \\
\hline & Low & $\begin{array}{l}3.3 \\
(2.5)\end{array}$ & $\begin{array}{r}35.2 \\
(6.7)\end{array}$ & $\begin{array}{r}23.7 \\
(6.0)\end{array}$ & $\begin{array}{r}15.6 \\
(5.1)\end{array}$ & $\begin{array}{l}1.1 \\
(1.4)\end{array}$ & $\begin{array}{r}21.2 \\
(5.7)\end{array}$ & 100.0 \\
\hline & Medium & $\begin{array}{r}15.2 \\
(6.2)\end{array}$ & $\begin{array}{r}38.9 \\
(8.4)\end{array}$ & $\begin{array}{r}25.7 \\
(7.5)\end{array}$ & $\begin{array}{l}7.5 \\
(4.5)\end{array}$ & $\begin{array}{l}0.0 \\
(0.1)\end{array}$ & $\begin{array}{r}12.7 \\
(5.7)\end{array}$ & 100.0 \\
\hline & High & $\begin{array}{r}21.7 \\
(5.3)\end{array}$ & $\begin{array}{r}43.7 \\
(6.4)\end{array}$ & $\begin{array}{r}25.5 \\
(5.6)\end{array}$ & $\begin{array}{l}7.9 \\
(3.5)\end{array}$ & $\begin{array}{l}1.2 \\
(1.4)\end{array}$ & $\begin{array}{l}0.0 \\
(0.2)\end{array}$ & 100.0 \\
\hline \multirow[t]{4}{*}{19 to 24} & Lowest & $\begin{array}{r}10.3 \\
(3.6)\end{array}$ & $\begin{array}{r}17.2 \\
(4.5)\end{array}$ & $\begin{array}{r}28.8 \\
(5.4)\end{array}$ & $\begin{array}{r}11.0 \\
(3.7)\end{array}$ & $\begin{array}{r}10.9 \\
(3.7)\end{array}$ & $\begin{array}{r}21.8 \\
(4.9)\end{array}$ & 100.0 \\
\hline & Low & $\begin{array}{l}8.8 \\
(6.8)\end{array}$ & $\begin{array}{r}14.5 \\
(8.4)\end{array}$ & $\begin{array}{l}50.2 \\
(12.0)\end{array}$ & $\begin{array}{l}5.5 \\
(5.5)\end{array}$ & $\begin{array}{l}2.1 \\
(3.5)\end{array}$ & $\begin{array}{r}18.9 \\
(9.4)\end{array}$ & 100.0 \\
\hline & Medium & $\begin{array}{r}22.2 \\
(8.7)\end{array}$ & $\begin{array}{r}10.2 \\
(6.4)\end{array}$ & $\begin{array}{r}32.8 \\
(9.9)\end{array}$ & $\begin{array}{l}7.2 \\
(5.4)\end{array}$ & $\begin{array}{l}2.8 \\
(3.5)\end{array}$ & $\begin{array}{r}24.7 \\
(9.0)\end{array}$ & 100.0 \\
\hline & High & $\begin{array}{r}23.8 \\
(7.7)\end{array}$ & $\begin{array}{r}32.1 \\
(8.4)\end{array}$ & $\begin{array}{r}34.3 \\
(8.5)\end{array}$ & $\begin{array}{l}3.6 \\
(3.3)\end{array}$ & $\begin{array}{l}0.9 \\
(1.7)\end{array}$ & $\begin{array}{l}5.3 \\
(4.0)\end{array}$ & 100.0 \\
\hline \multirow[t]{4}{*}{25 to 30} & Lowest & $\begin{array}{l}7.0 \\
(4.1)\end{array}$ & $\begin{array}{r}16.3 \\
(5.9)\end{array}$ & $\begin{array}{r}25.2 \\
(6.9)\end{array}$ & $\begin{array}{r}13.5 \\
(5.5)\end{array}$ & $\begin{array}{l}6.2 \\
(3.8)\end{array}$ & $\begin{array}{r}32.0 \\
(7.4)\end{array}$ & 100.0 \\
\hline & Low & $\begin{array}{r}16.1 \\
(8.1)\end{array}$ & $\begin{array}{l}35.5 \\
(10.6)\end{array}$ & $\begin{array}{l}36.5 \\
(10.6)\end{array}$ & $\begin{array}{l}0.0 \\
(0.1)\end{array}$ & $\begin{array}{r}10.6 \\
(6.8)\end{array}$ & $\begin{array}{l}1.2 \\
(2.4)\end{array}$ & 100.0 \\
\hline & Medium & $\begin{array}{l}8.1 \\
(5.8)\end{array}$ & $\begin{array}{l}37.7 \\
(10.4)\end{array}$ & $\begin{array}{l}44.4 \\
(10.6)\end{array}$ & $\begin{array}{l}0.0 \\
(0.1)\end{array}$ & $\begin{array}{l}1.5 \\
(2.6)\end{array}$ & $\begin{array}{l}8.3 \\
(5.9)\end{array}$ & 100.0 \\
\hline & High & $\begin{array}{l}9.1 \\
(3.6)\end{array}$ & $\begin{array}{r}31.5 \\
(5.8)\end{array}$ & $\begin{array}{r}45.7 \\
(6.3)\end{array}$ & $\begin{array}{l}5.6 \\
(2.9)\end{array}$ & $\begin{array}{l}1.1 \\
(1.3)\end{array}$ & $\begin{array}{c}7.0 \\
(3.2)\end{array}$ & 100.0 \\
\hline \multirow[t]{4}{*}{$>30$} & Lowest & $\begin{array}{l}5.6 \\
(3.2)\end{array}$ & $\begin{array}{r}14.3 \\
(4.9)\end{array}$ & $\begin{array}{r}16.9 \\
(5.3)\end{array}$ & $\begin{array}{r}17.5 \\
(5.3)\end{array}$ & $\begin{array}{l}6.2 \\
(3.4)\end{array}$ & $\begin{array}{r}39.5 \\
(6.9)\end{array}$ & 100.0 \\
\hline & Low & $\begin{array}{r}12.8 \\
(6.0)\end{array}$ & $\begin{array}{r}25.2 \\
(7.8)\end{array}$ & $\begin{array}{r}26.0 \\
(7.9)\end{array}$ & $\begin{array}{r}18.0 \\
(6.9)\end{array}$ & $\begin{array}{l}6.7 \\
(4.5)\end{array}$ & $\begin{array}{r}11.3 \\
(5.7)\end{array}$ & 100.0 \\
\hline & Medium & $\begin{array}{r}14.5 \\
(6.4)\end{array}$ & $\begin{array}{r}16.5 \\
(6.8)\end{array}$ & $\begin{array}{r}54.5 \\
(9.1)\end{array}$ & $\begin{array}{c}1.5 \\
(2.2)\end{array}$ & $\begin{array}{l}1.7 \\
(2.3)\end{array}$ & $\begin{array}{r}11.2 \\
(5.8)\end{array}$ & 100.0 \\
\hline & High & $\begin{array}{r}15.8 \\
(4.6) \\
\end{array}$ & $\begin{array}{r}45.1 \\
(6.2) \\
\end{array}$ & $\begin{array}{r}28.6 \\
(5.7) \\
\end{array}$ & $\begin{array}{r}3.6 \\
(2.3) \\
\end{array}$ & $\begin{array}{l}2.7 \\
(2.0) \\
\end{array}$ & $\begin{array}{r}4.3 \\
(2.5) \\
\end{array}$ & 100.0 \\
\hline Mean family profile & & 14.0 & 22.9 & 29.6 & 9.9 & 5.8 & 17.8 & 100.0 \\
\hline
\end{tabular}

Note: Standard errors in parenthesis. This table is graphically summarized in Figure 3 and 2A. 
Figure 2A: Dispersion clouds and confidence ellipses for family profiles by sex, race/ethnicity, age at migration, and educational attainment

Women

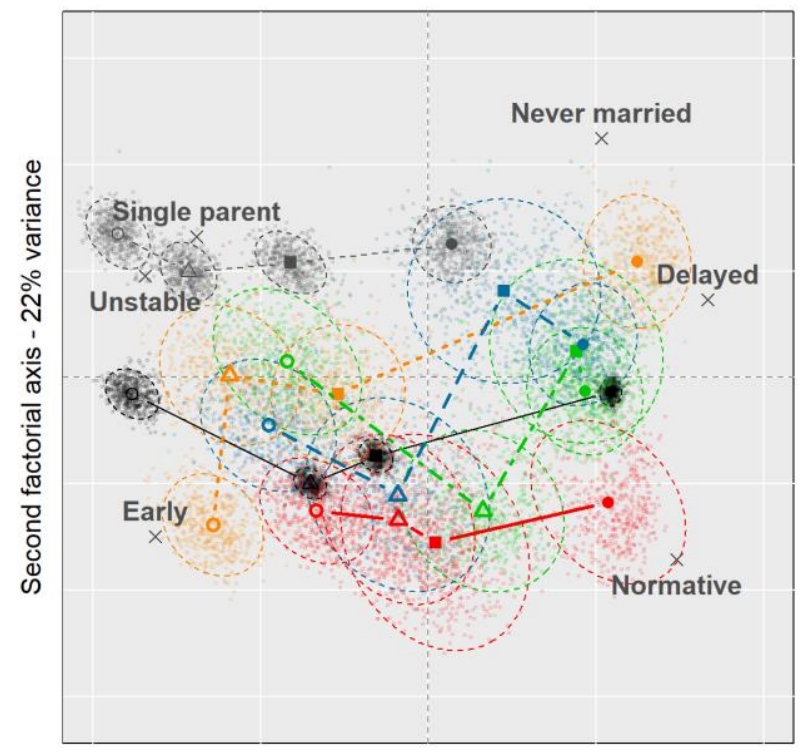

First factorial axis - 53\% variance
Men

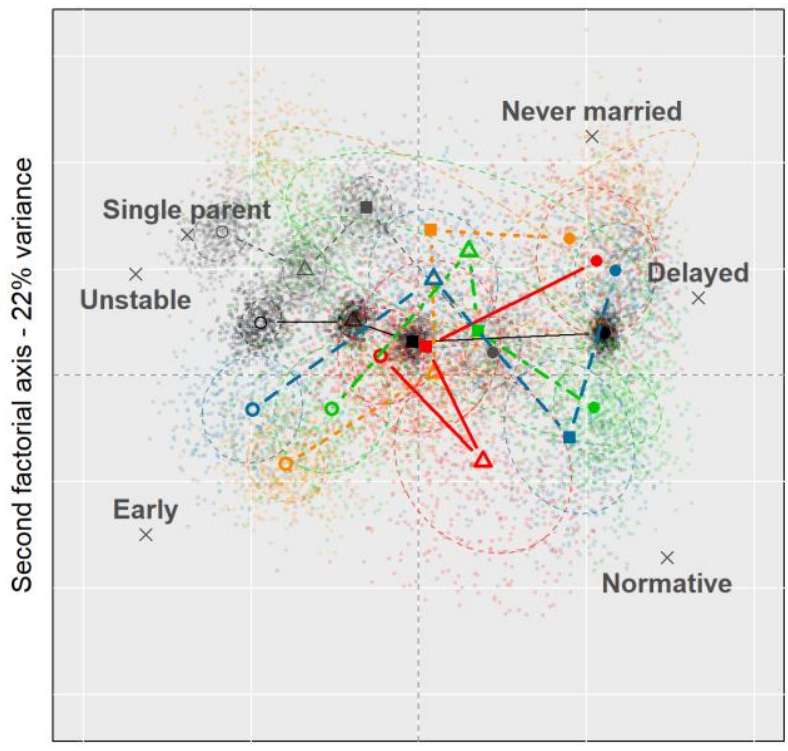

First factorial axis - $53 \%$ variance
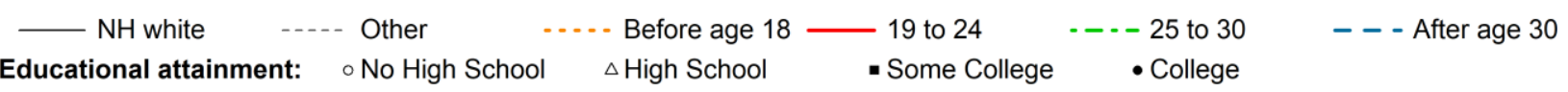

Notes: The mean profiles are (women-men): never-married (9.1\%-14.0\%), delayed (17.5\%$22.9 \%$ ), normative (28.6\%-29.6\%), unstable (9.2\%-9.9\%), single-parent (8.1\%-5.8\%), early (27.6\%-17.8\%). Background white lines are separated by one standard deviation. The $\%$ of variance of each axis refers to the total variance in Tables A4 and A5, and not to the variance of individual family trajectories.

Replications: Dispersion clouds are obtained by replicating Tables A4 and A5 500 times. Replications account for the estimated standard errors. Confidence ellipses include $85 \%$ of the points for women and $50 \%$ of the points for men. 